\title{
INVOLUNTARY RESETTLEMENT AND SUSTAINABLE DEVELOPMENT CONCEPTUAL FRAMEWORK, RESERVOIR RESETTLEMENT POLICIES, AND EXPERIENCE OF THE YUDONGXIA RESERVOIR
}

Nogendra Sapkota and Scott Ferguson

NO. 9

July 2017

\section{ADB EAST ASIA WORKING PAPER SERIES}


EARD Working Paper Series

\section{INVOLUNTARY RESETTLEMENT AND SUSTAINABLE DEVELOPMENT CONCEPTUAL FRAMEWORK, RESERVOIR RESETTLEMENT POLICIES, AND EXPERIENCE OF THE YUDONGXIA RESERVOIR}

Nogendra Sapkota and Scott Ferguson

No. 9 | July 2017 


\author{
(c) 2017 Asian Development Bank \\ 6 ADB Avenue, Mandaluyong City, 1550 Metro Manila, Philippines \\ Tel +632632 4444; Fax+6326362444 \\ www.adb.org \\ Some rights reserved. Published in 2017. \\ Printed in the Philippines. \\ Publication Stock No. WPS178903-2 \\ DOI: http://dx.doi.org/10.22617/WPS178903-2
}

The views expressed in this publication are those of the authors and do not necessarily reflect the views and policies of the Asian Development Bank (ADB) or its Board of Governors or the governments they represent.

ADB does not guarantee the accuracy of the data included in this publication and accepts no responsibility for any consequence of their use. The mention of specific companies or products of manufacturers does not imply that they are endorsed or recommended by ADB in preference to others of a similar nature that are not mentioned.

By making any designation of or reference to a particular territory or geographic area, or by using the term "country" in this document, $A D B$ does not intend to make any judgments as to the legal or other status of any territory or area.

This work is available under the Creative Commons Attribution 3.0 IGO license (CC BY 3.0 IGO) https://creativecommons.org/licenses/by/3.0/igo/. By using the content of this publication, you agree to be bound by the terms of this license. For attribution, translations, adaptations, and permissions, please read the provisions and terms of use at https://www.adb.org/terms-use\#openaccess

This CC license does not apply to non-ADB copyright materials in this publication. If the material is attributed to another source, please contact the copyright owner or publisher of that source for permission to reproduce it. ADB cannot be held liable for any claims that arise as a result of your use of the material.

Please contact pubsmarketing@adb.org if you have questions or comments with respect to content, or if you wish to obtain copyright permission for your intended use that does not fall within these terms, or for permission to use the ADB logo.

Note:

Corrigenda to ADB publications may be found at http://www.adb.org/publications/corrigenda 


\section{CONTENTS}

FIGURES AND TABLES

ACKNOWLEDGMENTS V V V V

EXECUTIVE SUMMARY vi

ABBREVIATIONS vii

$\begin{array}{ll}\text { I. INTRODUCTION } & 1\end{array}$

II. DISPLACEMENT AND RESETTLEMENT: CONCEPTUAL FRAMEWORKS

III. RESERVOIR RESETTLEMENT POLICIES AND PRACTICES

IN THE PEOPLE'S REPUBLIC OF CHINA 6

A. $\quad$ Policies and Practices at the National Level 6

B. Land Administration Law 6

C. Regulations for Water Conservancy Projects 7

D. Practices at Guizhou Province 9

E. The Asian Development Bank Experience with Dams and Reservoirs
in the People's Republic of China

IV. A CASE STUDY OF THE YUDONGXIA RESERVOIR IN GUIYANG MUNICIPALITY 10

A. Background and Context 10

B. Resettlement Scope of Yudongxia Reservoir 11

C. Assessment of Impacts and Resettlement Planning 13

D. Consultation, Participation, and Grievance Redress Mechanism 16

E. Compensation, Resettlement, and Rehabilitation Measures 17

F. Resettlement and Rehabilitation Measures for Seriously Affected Groups 21

G. Resettlement Monitoring and Evaluation 24

$\begin{array}{lll}\text { V. CONCLUSION } & 24\end{array}$

A. Conceptual Framework 24

B. National Context of Reservoir Resettlement Policies 25

C. Yudongxia Reservoir Case Study 25 


\section{FIGURES AND TABLES}

\section{FIGURES}

1 Scudder-Colson's Four-Stage Model 2

2 Cernea's Impoverishment Risks and Reconstruction Model 3

3 McDowell's Forced Displacement, Sustainable Livelihoods, and Impoverishment

4 Sustainable Developmental Resettlement Framework 5

\section{TABLES}

1 Summary of Resettlement Impacts $\quad 12$

2 Planning Steps 14

3 Summary Assessment of Key Resettlement Impacts 15

4 Compensation and Resettlement Measures 20 


\section{ACKNOWLEDGMENTS}

The authors-Nogendra Sapkota, senior social development specialist working at the Asian Development Bank (ADB); and Scott Ferguson, ADB's former principal social development specialist (safeguards)—would like to thank ADB's East Asia Department (EARD), particularly Qingfeng Zhang, director, Environment, Natural Resources, and Agriculture Division (EAER) of EARD, for encouraging the authors to publish the paper; and Ayumi Konishi, director general, EARD, for his endorsement of this publication. The authors appreciate the peer review and comments on the draft paper by Madhumita Gupta, principal social development specialist (Safeguards), EARD; Wenlong Zhu, senior safeguards officer, ADB Resident Mission in the People's Republic of China (PRC); and Vergel Medina, social development specialist (Safeguards), Environment and Safeguards Division, Sustainable Development and Climate Change Department.

The authors also acknowledge the support of Heidee Luna and Joy Quitazol-Gonzalez, EAER; Reynaldo Ablanida, Ruby Anne Angeles, Emmalou Guillarte, Cecille Paña, Robert Schoellhammer, and Akiko Terada-Hagiwara, EARD; Marzia Mongiorgi-Lorenzo, PRC Resident Mission; and Rodel Bautista, Ma. Katrina Fernando, and Cynthia Hidalgo, Department of External Relations, for their help in the publication process. 


\section{EXECUTIVE SUMMARY}

Involuntary resettlement is a complex issue and requires good knowledge, policies, and practices to manage it successfully, particularly in reservoir projects. Most conceptual frameworks focus on analysis of adverse impacts of resettlement, and some are development-oriented. The framework that focuses on sustainable development outcomes for relocated people provides a more comprehensive approach to study and manage involuntary resettlement.

National resettlement policies play an important role in determining the resettlement and rehabilitation outcomes. Results of reservoir-related resettlement were problematic during the first two decades of the People's Republic of China (PRC). However, several good policies and legislations have been enacted and implemented since the mid-1980s to improve resettlement and rehabilitation outcomes, particularly for large- and medium-sized reservoir projects.

The case study of the Yudongxia Reservoir in the PRC, a reservoir project financed by the Asian Development Bank which has 20 years of experience with dam and reservoirs projects in the PRC, shows successful overall results in compensation and resettlement of relocated people; although some rehabilitation measures showed mixed results. The reconstruction of the relocated families' houses and the restoration of their community assets, cultural resources, and living environment were largely successful. There were some challenges in the restoration of food production and agricultural employment. Access to health and educational services did not have major issues. Monitoring and evaluation were regularly conducted.

This paper synthesizes the conceptual framework on involuntary resettlement, the PRC's policies regarding reservoir-related resettlement, and the experience of the Yudongxia Reservoir in resettlement, focusing on sustainable development outcomes for relocated people. 


\section{ABBREVIATIONS}

\begin{tabular}{|c|c|c|}
\hline AAOV & - & average annual output value \\
\hline ADB & - & Asian Development Bank \\
\hline DMS & - & detailed measurement survey \\
\hline GIWRMP & - & Guiyang Integrated Water Resources Management (Sector) Project \\
\hline IRR & - & impoverishment risk and reconstruction \\
\hline LAL & - & Land Administration Law \\
\hline LAR & - & land acquisition and resettlement \\
\hline MDB & - & multilateral development bank \\
\hline mu & - & a Chinese unit of land measurement $(1 \mathrm{mu}=0.067$ hectare $)$ \\
\hline MWR\&EP & - & Ministry of Water Resources and Electric Power \\
\hline PRC & - & People's Republic of China \\
\hline
\end{tabular}





\section{INTRODUCTION}

Project designers and implementers must consider the need for land acquisition and resettlement (LAR) and its impacts on people. Land is required in transport, energy, urban development, and other infrastructure projects that help the public. While state land is one source, suitable state land may often be unavailable or inadequate. In such situations, projects need to acquire nonstate land that collectives, farmers, or private entities may either own or use. LAR is a complex process involving social issues. It leads to loss of livelihoods and income-generating assets for local people and displaces them from their homes. It affects direct land occupants or users, landowners, and local and neighboring communities.

If $L A R$ is unavoidable, fulfilling legal requirements and managing social impacts become an integral part of project management. Managing social impacts requires in-depth knowledge on how to lessen the impacts, and compensate and rehabilitate affected people.

This paper presents (i) a sustainable developmental resettlement framework by reviewing and synthesizing the existing frameworks on involuntary resettlement; (ii) an overview of reservoir resettlement policies and practices in the People's Republic of China (PRC); and (iii) a case study on the Yudongxia Reservoir in the PRC's Guizhou Province, a reservoir project financed by the Asian Development Bank (ADB). ${ }^{1}$

This knowledge product aims to guide the design and implementation of projects involving LAR.

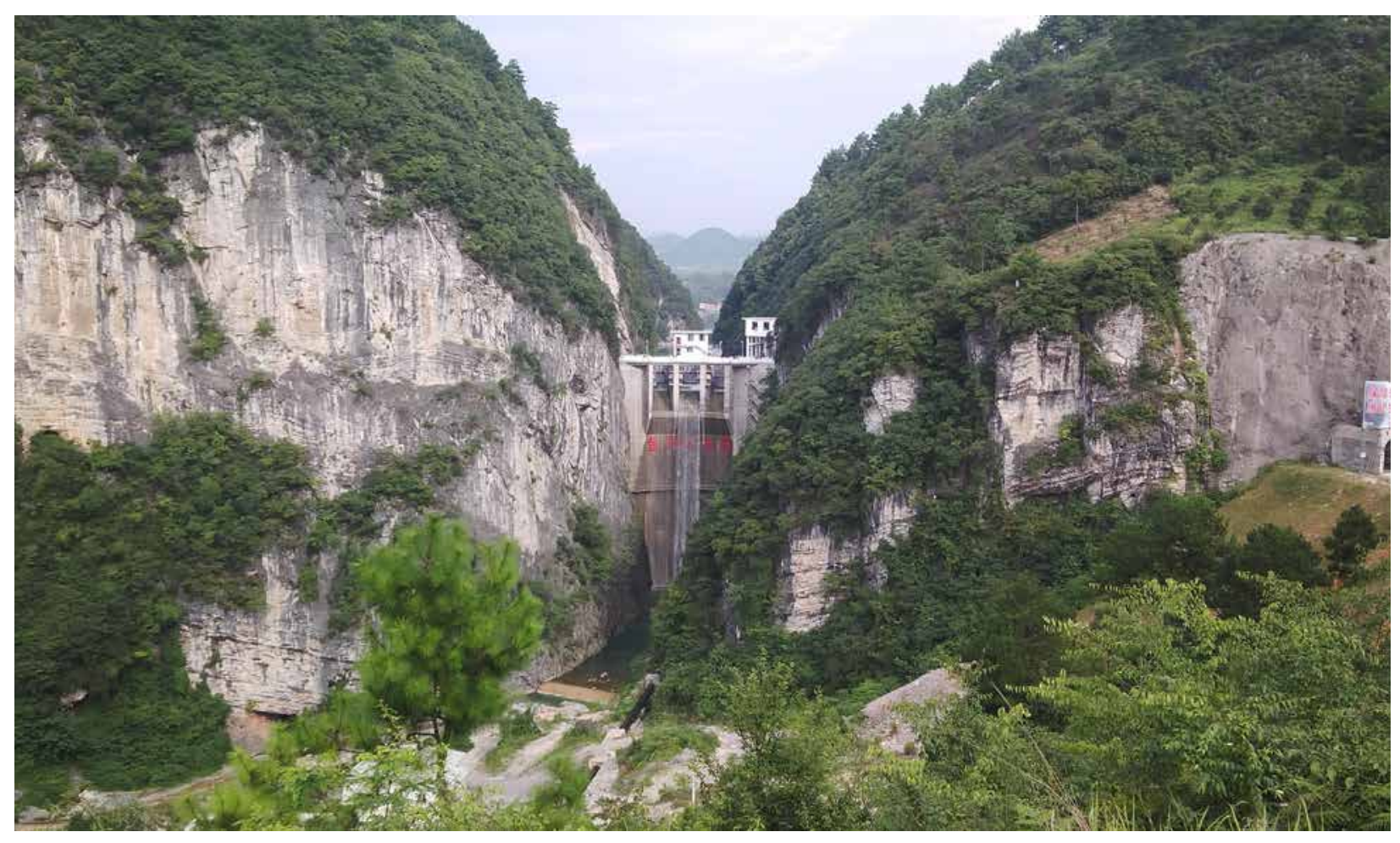

Yudongxia Dam and Reservoir.

Photo credit: Nogendra Sapkota.

1 The Yudongxia Reservoir was selected as a case study because it involved significant resettlement impacts among ADB's recently completed reservoir projects. 


\section{DISPLACEMENT AND RESETTLEMENT: CONCEPTUAL FRAMEWORKS}

Most infrastructure projects such as roads, irrigation, and hydropower involve land acquisition and resettlement (LAR) and often lead to the physical and socioeconomic displacement of people to make space for their construction and operation. Development projects displace about 10 million people globally each year. ${ }^{2}$ Reservoir projects cause the most severe impacts. Displaced persons are more vulnerable due to change in traditional socioeconomic systems and loss of livelihoods. ${ }^{3}$

There have been several conceptual frameworks developed since the 1970s to analyze and understand displacement and resettlement issues. In the late 1970s, Scudder and Colson developed a four-stage model to study voluntary resettlement. The model was refined in the 1980s to examine the involuntary resettlement process. ${ }^{4}$ Based on this model, every resettled community passes through the following stages (Figure 1): (i) planning and recruitment, (ii) adjustment and coping, (iii) community formation and economic development, and (iv) turnover and incorporation. Certain behavioral patterns characterize each stage (footnote 4). During planning and recruitment, project developers and planners prepare development and resettlement plans. During adjustment and coping, displaced persons prepare for future displacement with heightened mental stresses. During community formation and economic development, actual physical relocation occurs, and displaced persons rebuild their economy and social networks. During turnover and incorporation, the second generation of displaced persons takes over local production systems and community leadership positions. Resettlement programs are successful if they pass with ease through all the four stages, and are sustainable to the second generation of displaced persons. However, evidence from involuntary resettlement shows that not all programs pass through all the stages successfully (footnote 2 ).

\section{Figure 1: Scudder-Colson's Four-Stage Model}

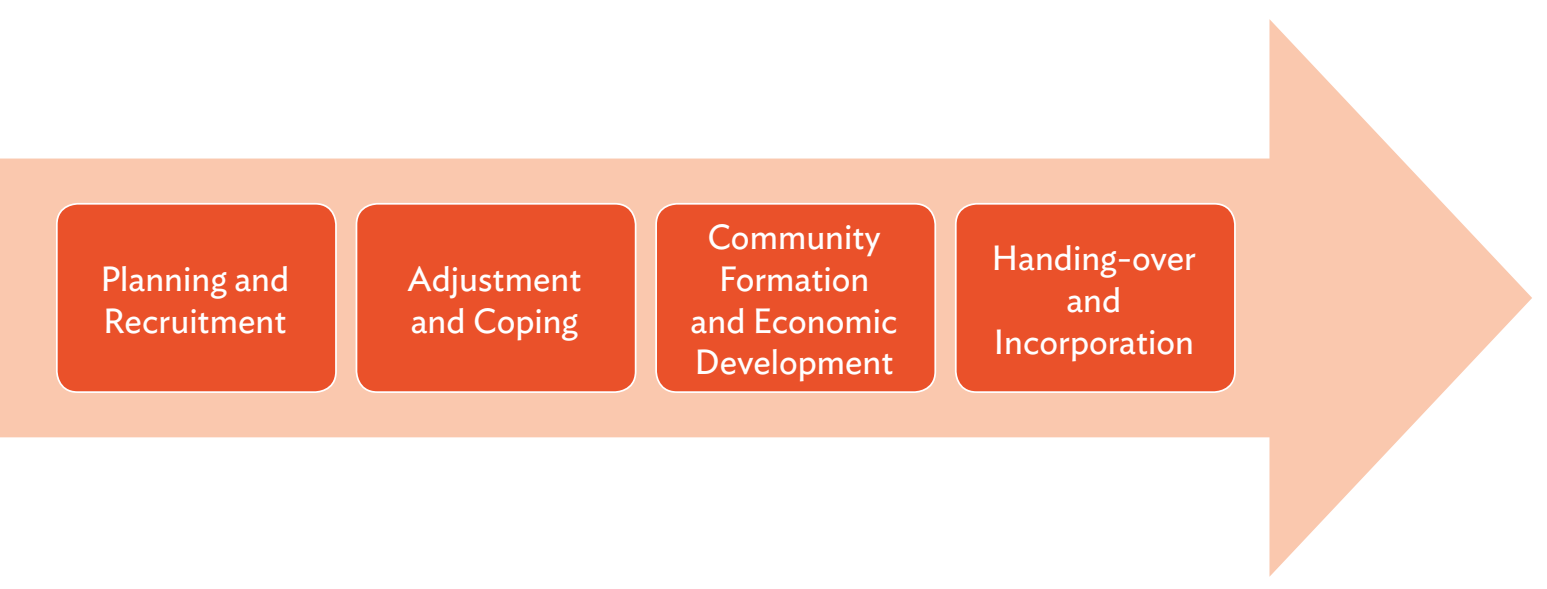

Source: T. Scudder. 2005. The Future of Large Dams. London: Earthscan.

2 M. Cernea. 2004. Impoverishment Risks, Risk Management, and Reconstruction: A Model of Population Displacement and Resettlement. Paper presented at the United Nations Symposium on Hydropower and Sustainable Development. Beijing. 27-29 October. https://commdev.org/wp-content/uploads/2015/06/Impoverishment-Risks-Risk-Managementand-Reconstruction.pdf

3 The terms "displaced persons" and "affected persons" have the same meaning, but this paper uses "displaced persons."

4 T. Scudder. 2005. The Future of Large Dams. London: Earthscan. 
The impoverishment risks and reconstruction (IRR) model developed in the 1990s by M. Cernea did not identify the different stages as in Scudder-Colson's four-stage model. Instead, it described eight major impoverishment risks on involuntary resettlement and recommended a similar number of measures to rebuild the livelihoods of displaced persons (Figure 2). Based on this model, the eight risks of impoverishment that accompany involuntary resettlement are landlessness, joblessness, homelessness, marginalization, food insecurity, increased morbidity and mortality, loss of access to common property resources, and community disarticulation (footnote 2 ). The IRR model advocates for targeted measures to address the risks: land-based resettlement, job creation, housing, health and nutritional measures, and social network rebuilding. ${ }^{5}$

Downing and others included additional risks to the IRR model, such as losing access to public services, disrupting formal education activities, losing civil and human rights, and increased costs in resettlement areas. ${ }^{6}$ Scudder suggested combining his four-stage model and the IRR model into a single framework.

\section{Figure 2: Cernea's Impoverishment Risks and Reconstruction Model}
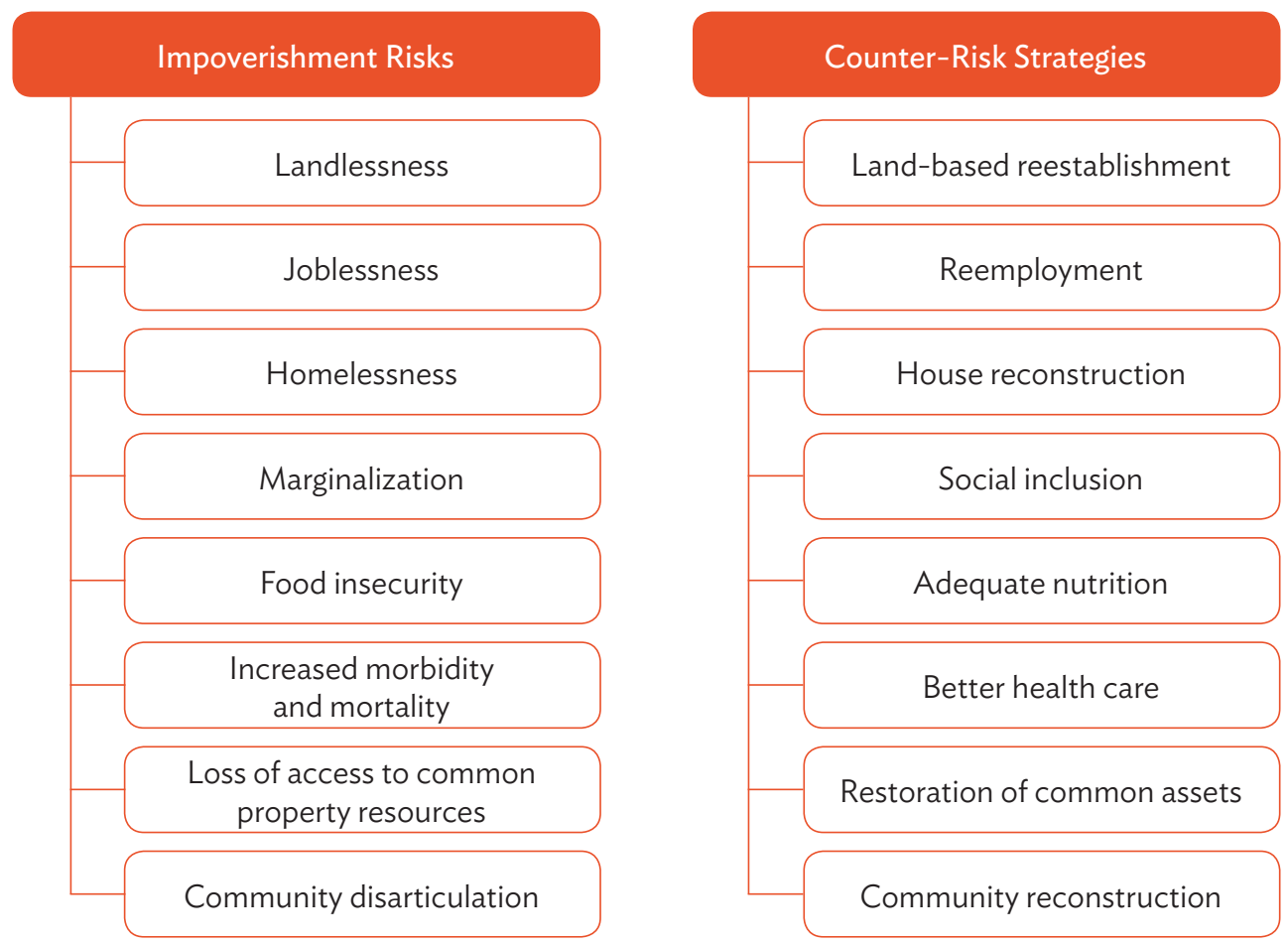

Sources: M. Cernea. 2004. Impoverishment Risks, Risk Management, and Reconstruction: A Model of Population Displacement and Resettlement. Paper presented at the United Nations Symposium on Hydropower and Sustainable Development. Beijing. 27-29 October. https://commdev.org/wp-content/uploads/2015/06/Impoverishment-Risks-Risk-Management-and-Reconstruction. pdf ; and M. Cernea. 1997. The Risks and Reconstruction Model for Resettling Displaced Populations. World Development. 25 (10). pp. 1569-1587. http://chs.ubc.ca/srilanka/PDFs/Model\%20for\%20 resettling\%20displaced\%20populations.pdf

5 M. Cernea. 1997. The Risks and Reconstruction Model for Resettling Displaced Populations. World Development. 25 (10). pp. 1569-1587. http://chs.ubc.ca/srilanka/PDFs/Model\%20for\%20resettling\%20displaced\%20populations.pdf

6 T. Downing. 2002. Avoiding New Poverty: Mining-induced Displacement and Resettlement. MMSD Report 58. London: IIED. http://pubs.iied.org/pdfs/G00549.pdf 
McDowell proposed a framework of "forced displacement, sustainable livelihoods, and impoverishment risks" by combining the IRR model and the elements of sustainable livelihoods approach previously used in poverty reduction and development fields. ${ }^{7}$ Based on this framework, sustainable livelihood outcomes depend on multiple sets of factors, including impoverishment risks, livelihood strategies that operate in specific political and social context, livelihood resources, and institutional processes (Figure 3 ).

\section{Figure 3: McDowell's Forced Displacement, Sustainable Livelihoods, and Impoverishment Risks Framework}
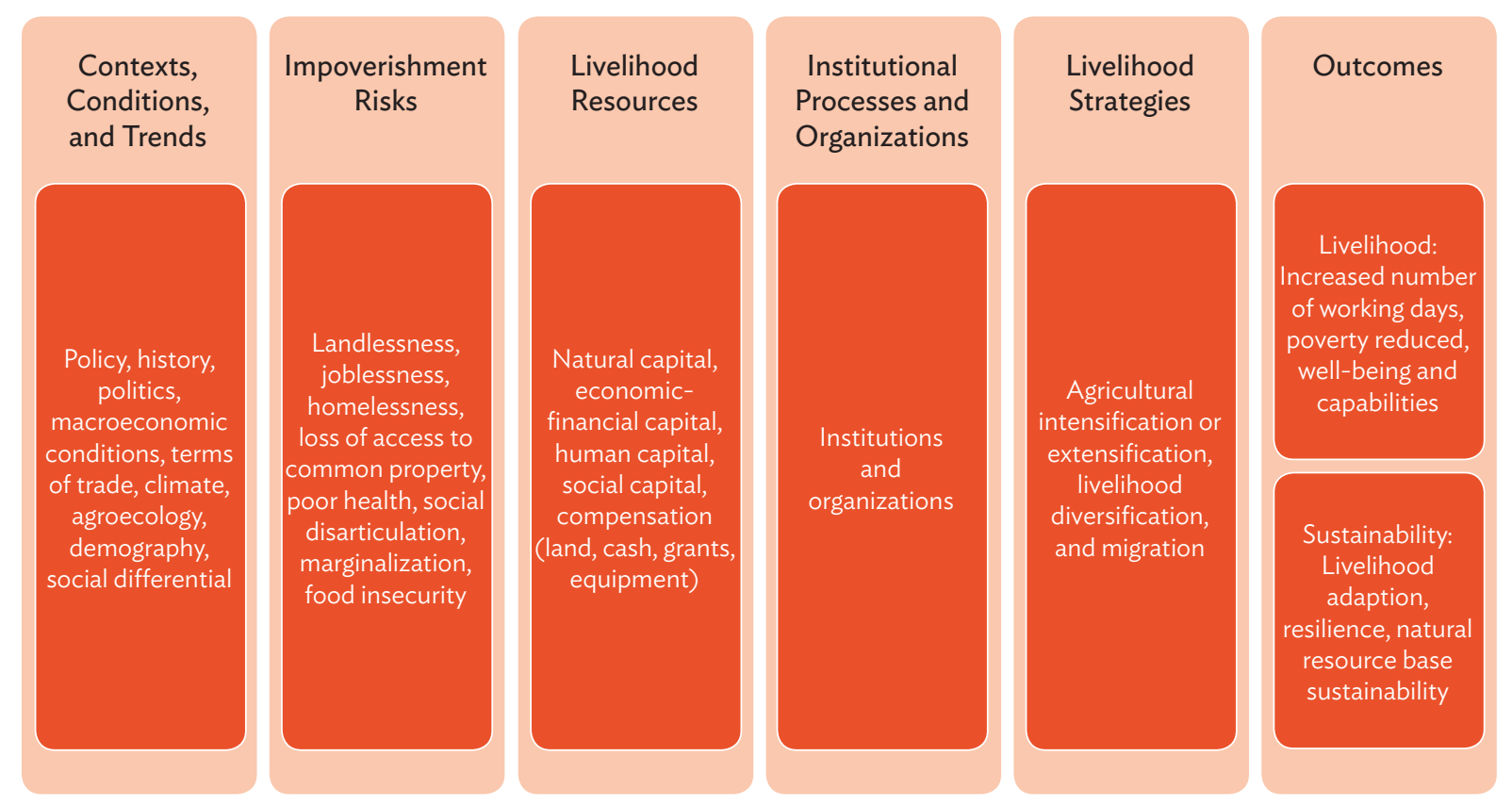

Source: C. McDowell. 2002. Involuntary Resettlement, Impoverishment Risks, and Sustainable Livelihoods. The Australasian Journal of Disaster and Trauma Studies. 2. http://trauma.massey.ac.nz/issues/2002-2/mcdowell.htm

Along with the analytical models, some development-oriented resettlement policy frameworks have evolved since the 1980s. Multilateral development banks (MDBs), including the World Bank and $\mathrm{ADB}$, adopted resettlement policies promoting sustainable resettlement and livelihood restoration for displaced persons in development projects. Key elements of the MDB resettlement policies include (i) minimizing resettlement by exploring design options; (ii) improving or restoring livelihoods of displaced persons by proper assessment, planning, and management of LAR; (iii) making efforts to share project benefits; (iv) ensuring participation of displaced persons; ( $v$ ) considering the needs of host communities; and (vi) addressing the needs of vulnerable groups. Several developing countries, including those in Asia and the Pacific that received support from MDBs, developed national resettlement policies reflecting elements of development-oriented resettlement.

7 C. McDowell. 2002. Involuntary Resettlement, Impoverishment Risks, and Sustainable Livelihoods. The Australasian Journal of Disaster and Trauma Studies. 2. http://trauma.massey.ac.nz/issues/2002-2/mcdowell.htm 
Restoring and achieving sustainable livelihoods is the most challenging and common issue in LAR. More and more overall development frameworks incorporate ideas of sustainability and livelihoods. The recent United Nations Conference in 2015 adopted 17 Sustainable Development Goals. ${ }^{8}$ Of the 17 goals, goals 1-9 are relevant to sustainable resettlement and livelihood restoration for displaced persons. The authors of this paper propose a sustainable developmental resettlement framework that combines resettlement and sustainable development outcomes (Figure 4). It is a comprehensive framework for assessing resettlement impacts, planning resettlement and rehabilitation programs, and monitoring and evaluating program outcomes.

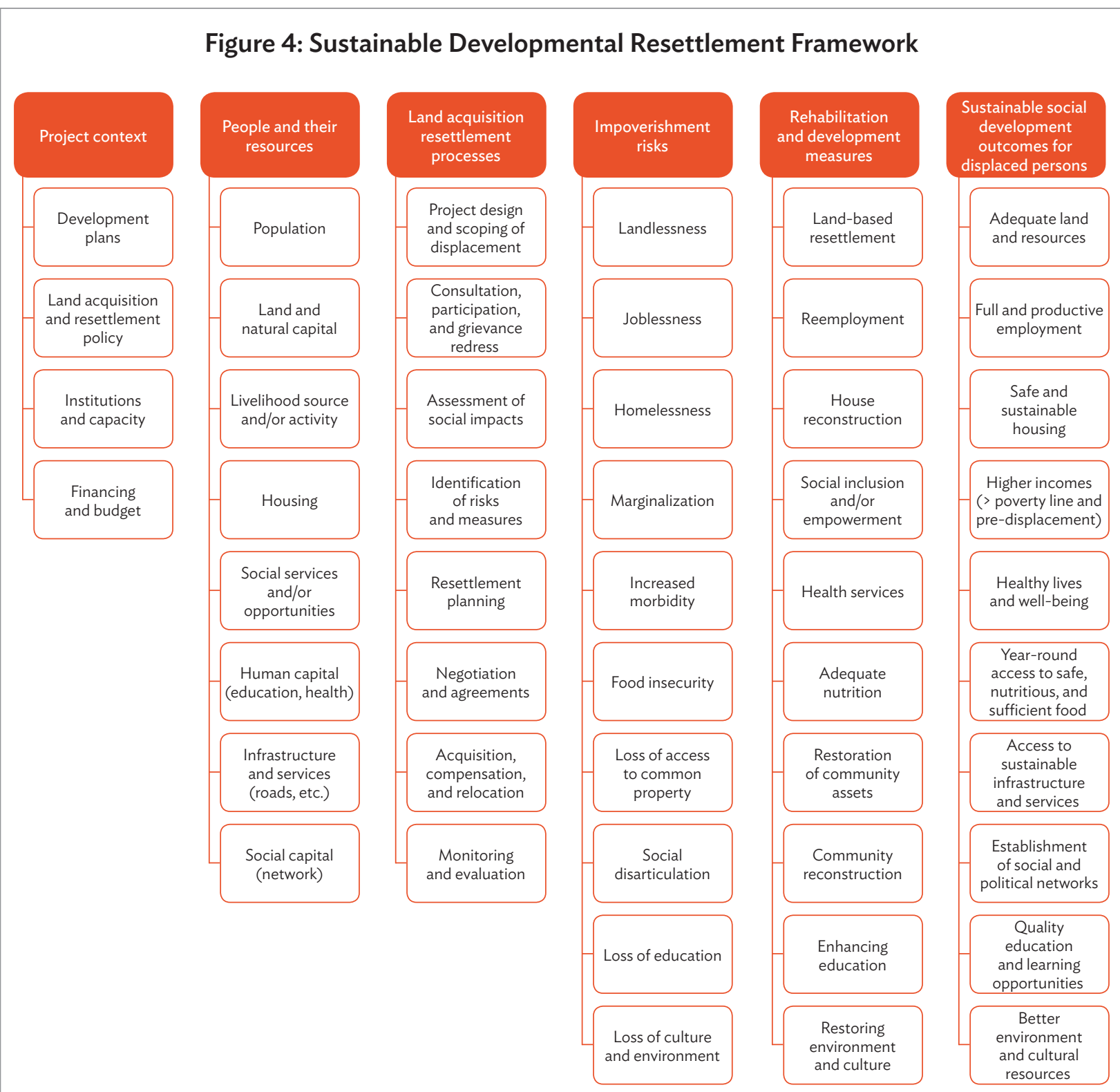

Source: Authors.

8 United Nations. Sustainable Development Goals: 17 Goals to Transform our World. http://www.un.org/sustainabledevelopment/ sustainable-development-goals/ 


\section{RESERVOIR RESETTLEMENT POLICIES AND PRACTICES IN THE PEOPLE'S REPUBLIC OF CHINA}

\section{A. Policies and Practices at the National Level}

In the 1950s, the PRC prioritized water conservancy projects during its era of dam construction and received technical support from the former Soviet Union. ${ }^{9}$ The Ministry of Water Resources and Electric Power (MWR\&EP) led this development until the separation of water and electric power responsibilities into two ministries in the 1990s. Until 1985, legislation was weak to address land acquisition and resettlement (LAR). Many dam projects caused large-scale resettlement. Project implementation plans included the management of these issues and related costs. However, the budget to resettle people and restore their livelihoods was often insufficient. The macroeconomic and national social conditions occurring during those times - such as the transition to socialism and collectivization of farmland (19531957), the Great Leap Forward (1958-1961), famine in 1961, the Cultural Revolution (1966-1976), and reformist policies and break-up of communes (1977-1980)-helped mask widespread evidence of resettlement challenges and adverse impacts. In the 1980s, the PRC implemented economic and social reforms that opened it up to the outside world and allowed it to start engaging with multilateral financial institutions. Many legislative reforms to drive economic growth also addressed LAR.

\section{B. Land Administration Law}

The new Land Administration Law (LAL), ${ }^{10}$ issued on 25 June 1986, addressed the acquisition of collectively owned land or the use of state-owned land for construction projects. ${ }^{11}$ It became effective on 1 January 1987. ${ }^{2}$ The LAL set out the requirements for acquisition or land transfer and compensation; the use of compensation funds; temporary use of land; and livelihood restoration or reemployment, including change in household registration if all land is requisitioned. ${ }^{13}$ Based on the LAL, "no unit or individual may seize, buy, sell, or lease land; or make any other unlawful transfer of land."14 The 1986 LAL established low compensation standards ${ }^{15}$ based on the presumption that displaced persons should contribute to the common good until the PRC achieved higher economic standards. ${ }^{16}$ If compensation

9 Water conservancy is a broad term used in the PRC referring to flood management, water supply, and river and/or reservoir engineering works.

10 Government of the PRC. 1986. Land Administration Law of the People's Republic of China. Beijing.

11 The LAL superseded the "Regulations on the Requisition of Land for State Construction" issued by the State Council in 1982. In 1991, there was a separate decree No. 55 for "Transferring the Right to Use State-owned Land in Cities and Towns." So, the LAL continues to focus on rural areas and collectively owned lands in urban areas.

12 Implementation regulations for the LAL were implemented later that year by local governments at the provincial level. The national regulation (Decree No. 73 of the State Council) was not issued until 4 January 1991, which required provincial regulations to be updated.

13 Footnote 10, Chapter IV.

14 These limitations would gradually be relaxed over time. In 1988, the LAL clause was amended to delete the word "lease;" and, in 2006, the Ministry of Agriculture passed a regulation to allow the transfer of land use rights (essentially long-term leasing of collective lands).

15 The LAL stipulated compensation of 3 to 6 times the average annual output value (AAOV) for cultivated land, and local governments will set rates for other types of land and for attachments. In addition, resettlement subsidies for 2 to 3 times the AAOV of cultivated land would be paid based on dividing the amount of cultivated land acquired by the average land holding (for water conservancy projects, this is usually interpreted as a payment per "resettled person" rather than the unit of land acquired).

16 This became a fundamental principle for the water resources sector, since most projects were seen to provide long-term economic benefits and may not provide immediate returns on investment (e.g., management of flood risks as opposed to generation of electricity). That is why, since 1990, power companies develop projects that are purely for hydroelectric power rather than the Ministry of Water Resources (MWR). The MWR develops other projects, including multi-purpose projects. Nonetheless, all such large- and medium-scale projects need to comply with the MWR regulations. 
and subsidies are insufficient, the LAL states that the local government can increase the amount. However, guidance on how to measure sufficient compensation was not provided. ${ }^{17}$ The LAL states that the State Council will be responsible for stipulating requirements on large- and medium-sized water conservancy or hydroelectric project construction.

More broadly, the LAL also established the (i) land contracting system and individual user rights with a dispute resolution system; (ii) use of land for town or village construction; and (iii) norms that land should be valued highly and utilized rationally, including a land reclamation requirement in case a farmland was acquired for construction. While these would discourage the use of valuable farmland for construction projects, it has taken many years to institutionalize. ${ }^{18}$ The 1988 amendment of the LAL addressed cut-off dates for construction. The 1999 amendment increased citizen participation, raised compensation standards 10-30 times the average annual output value (AAOV), and mainstreamed approval procedures for land use. ${ }^{19}$ Amendments in 2004 improved the approval process by clarifying responsibilities; raised compensation standards to a minimum of 16 times the AAOV; established due process, including consultation with affected persons; and strengthened administrative and supervision procedures. However, the preparation and disclosure of a resettlement plan prior to project approval was still not required. Even during implementation, the detailed implementation plans are not disclosed to the public. In addition, the LAL was not explicit on rural housing demolition and reconstruction; instead, this was addressed by the local government regulations and standards.

\section{Regulations for Water Conservancy Projects}

On 31 December 1984, the MWR\&EP issued specifications on "Reservoir Inundation Treatment for Water Conservancy and Hydropower Projects." These specifications served as a guide on how to calculate the scope of reservoir inundation, address resettlement issues, plan for the development and clearing of the reservoir area, and calculate reservoir investment and compensation. ${ }^{20}$ During the drafting of the first LAL, it was apparent that water conservancy projects could cause significant resettlement; hence, the MWR\&EP drafted a separate legislation to address this.

On 1 May 1991, the State Council issued the Regulations on Land Acquisition Compensation and Resettlement for the Construction of Large- and Medium-Sized Water Conservancy and Hydropower Projects, ${ }^{21}$ which conformed to the pending $L A L$ and the Water Law. ${ }^{22}$ This regulation introduced the concept of compensation and subsidy in the initial stage and support in the later stage, and demanded resettlement plans to coordinate with reservoir area development and water and soil conservation requirements. Though the State Council regulation preferred resettlement within the same township, the regulation also introduced various strategies for resettlement, such as nearby or long-distance moves and the use of reservoir resources or wastelands. The regulation also defined the principles of compensation, compensation standards, and the administrative responsibilities for resettlement planning and implementation.

17 The aggregate multiple can be increased to a maximum of 20 times the AAOV.

18 Although compensation standards have increased over time, local governments set the standards. Some provinces, like Yunnan, now place a high premium on the acquisition of basic farmland.

19 Government of the PRC. 1999. Land Administration Law of the People's Republic of China (and amended in 2004). Beijing.

20 The Water Conservancy and Hydropower Investigation and Design General Institute also issued detailed regulations in 1986 and 1989 based on the design specifications.

${ }^{21}$ Government of the PRC, State Council. 1991. Regulations on Land Acquisition Compensation and Resettlement for the Construction of Large- and Medium-Sized Water Conservancy and Hydropower Projects. Beijing.

${ }^{22}$ Clause 23 of the Water Law of the People's Republic of China (1988) stipulates that "local government shall assume the responsibility for properly arranging the subsistence and production of people to be resettled due to the construction of water conservancy projects. The cost for such resettlement shall be listed in the project investment ..." The PRC's Water Law is available at http://english.mofcom.gov.cn/article/lawsdata/chineselaw/200211/20021100053796.shtml 
Unfortunately for large reservoirs, land compensation standards were only 3-4 times the AAOV under the regulation, lower than the LAL standards. ${ }^{23}$ Yet, Article 6 of the regulation stated that higher compensation is possible if the social impacts or land losses are very severe. ${ }^{24}$ Farmers' hukous ${ }^{25}$ could also change if they lost most of their farmland. Importantly, Article 10 of Chapter 3 stipulates that submissions of preliminary design documents will not be examined and approved-nor can land acquisition begin-unless they come with a resettlement program prepared by the project owner together with the local government. Other construction projects do not have such a requirement so far. One unique feature of reservoir resettlement in the PRC is that project owners prefer to manage the resettlement program as part of the project, including the development of resettlement sites. This was common for large-scale impacts and often done to keep resettlement costs lower. It also meant that displaced persons had few choices and had to follow the resettlement program. Today, local governments prefer the more common cash compensation, especially for small-scale impacts, that allows displaced persons to choose from livelihood options based on their means and preferences. While the 1991 Regulation states 5 to 10 years of postresettlement support, it lacked any further details on the subject, which then had to be established for each project. Also, postresettlement support programs were more relevant to hydropower projects, which generated revenues. Other water conservancy projects faced financial difficulties implementing postresettlement support programs.

The 2006 revision of the regulation provides more explicit requirements and procedures, especially for resettlement planning and postresettlement support. ${ }^{26} \mathrm{~A}$ new Article 5 strengthened management systems by instituting a Resettlement Office under the State Council. Local governments made similar arrangements to ensure the coordinated implementation of resettlement. A new Chapter II for resettlement planning includes Articles 6 to 19. Article 6 clarifies the resettlement planning and approvals procedures. Article 7 requires an outline for resettlement planning based on physical surveys; consultation with affected villages, host villages, and local government; and notification to affected people. Articles 8 and 9 stipulate the contents of the planning outline. Article 10 provides the examination and approval procedures, which now occur at a much earlier stage of project planning. Article 11 is important because it emphasizes the need to consider the (i) carrying capacity of the resettlement areas; (ii) production, living styles, and customs of displaced persons and host people; and (iii) resettlement planning combined with the local development plans. Articles 12 and 13 focus on rural resettlement, and Article 14 focuses on urban resettlement concerns. Article 15 highlights consultations and hearings with displaced persons and host communities, and emphasizes strict adherence to resettlement plans. For any significant changes, the revised plan must undergo reexamination and reapproval. Land use formalities are not processed without such approvals. Article 16 demands resettlement costs based on the stipulations of the State Council and local governments rather than the MWR\&EP. This improved compensation levels but increased the cost of projects. Articles 17 and 18 stipulate planning requirements for resettlement sites, including environmental assessment. Chapter III is for land acquisition compensation. Article 20 highlights the need to include land acquisition in the annual land allocation of local governments, making it more difficult to get approval for projects that inundate large amounts of basic farmland. Article 22 demands a minimum land compensation of 16 times the AAOV, consistent with the LAL. Under Article 25, the farmland created for resettlers may offset cash compensation. However, in line with environmental requirements, the slope land above $25^{\circ}$ is not counted as farmland, which

\footnotetext{
${ }^{23}$ For medium reservoir, the provincial government determines land compensation standards. The provincial government also sets all other compensation standards (e.g., housing and attachments).

${ }^{24}$ Up to 20 times if the average remaining farmland is less than 0.5 mu per capita.

${ }^{25}$ Hukou means the registration system where people are registered as either urban residents or rural residents.

${ }^{26}$ Government of the PRC, State Council. 2006. Regulations on Land Acquisition Compensation and Resettlement for the Construction of Large- and Medium-Sized Water Conservancy and Hydropower Projects. Beijing.
} 
could have adverse effects on the livelihood of farmers. Chapter IV is for resettlement provisions. Article 27 requires resettlement agreements signed with local governments before construction can begin. Subsequent articles demand annual resettlement plans during implementation, and timely payment of compensation and other resettlement costs. Article 37 requires a final evaluation and acceptance of the resettlement implementation by higher officials. A new Chapter $V$ explained in detail the scope and length of support in the later stage. Under Article 38, local governments will develop and implement the support plans. Article 40 says that resettlers should receive support as livelihood and production subsidies, and may include development projects. Article 41 emphasizes the need for infrastructure improvements in the host area to support production rehabilitation. Article 43 has provisions for the drawdown zone within the new reservoirs. A new Chapter $\mathrm{VI}$ strengthens the procedures for supervision and management, including the evaluation of living standards of displaced households. The technicians who prepare resettlement plans should pass examinations. Articles 53 and 55 have general provisions for disclosure of information and grievance redress. Chapter VII is more explicit on legal liabilities and penalties for mismanagement of resettlement. This helped to prevent local officials from abusing resettlement funds, which occurred on previous projects.

A noteworthy provision in the regulation is the policy that requires postresettlement support to displaced persons for 20 years, which is a unique resettlement policy for reservoir projects in the PRC. This is a good practice to secure long-term livelihood for displaced persons.

\section{Practices at Guizhou Province}

Guizhou is one of the provinces in the PRC with a resettlement bureau. This is due to the great number of large, medium, and small water resource projects implemented in Guizhou. The knowledge of local officials has evolved along with project experience and improvement in laws and regulations. For the Guiyang Integrated Water Resources Management (Sector) Project (GIWRMP), the Guizhou Provincial Government applies the 2006 version of the regulation even for small reservoirs. ${ }^{27}$ This gave ADB firsthand experience on domestic procedures.

\section{E. The Asian Development Bank Experience with Dams and Reservoirs in the People's Republic of China}

ADB has 20 years of experience with dam and reservoirs projects in the PRC, beginning with the Linjingtan Hydropower Project in Hunan that resettled 6,000 persons, the Mianhuatan Water Resources Project in Fujian that resettled 39,400 persons, and the Shanxi Water Supply Project in Zhejiang that resettled 37,250 persons in two reservoirs. ${ }^{28}$ Most ADB-financed dam and reservoir projects have since been for water supply, and most of these were medium- or small-scale projects and involved less resettlement. ${ }^{29}$ Although the more recent projects have smaller impacts, the issues are still similar. However, large-scale village and town relocation is rare. The experience gained and lessons learned contributed to the resettlement planning and implementation of the GIWRMP.

27 ADB. 2009. Report and Recommendation of the President to the Board of Directors: Proposed Loan to the People's Republic of China for the Guiyang Integrated Water Resources Management (Sector) Project. Manila. http://www.adb.org/projects/38594-013/ main\#project-documents

${ }^{28}$ Hunan Linjingtan Hydropower (Loan 1318-PRC approved in 1994), Fujian Mianhuatan Water Resources (Loan 1417-PRC approved in 1995), and Zhejiang Shanxi Water Supply (Loan 1544-PRC approved in 1997).

29 Hebei Zhanghewan Pumped Storage (Loan 1922-PRC approved in 2002), Heilongjiang Harbin Water Supply (Loan 1995PRC approved in 2003), Kunming Qingshuihai Water Supply (Loan 2388-PRC approved in 2007), Guizhou Guiyang Integrated Water Resources (Loan 2573-PRC approved in 2009), and Shandong Reservoir Strengthening (Loan 2700-PRC approved in 2010). 


\section{A CASE STUDY OF THE YUDONGXIA RESERVOIR IN GUIYANG MUNICIPALITY}

\section{A. Background and Context}

In 2009, ADB approved the Guiyang Integrated Water Resources Management (Sector) Project (GIWRMP), and its largest subproject was the Yudongxia Reservoir. The GIWRMP was created during the Eleventh Five-Year Plan of the PRC to help implement the policies and plans of the PRC, the Guizhou Provincial Government, and the Guiyang Municipal Government. The GIWRMP's estimated cost is $\$ 439.2$ million, including $\$ 150.0$ million of ADB financing. The GIWRMP aims to (i) introduce integrated water resources management as stipulated in the 2002 Water Law; (ii) finance a slice of the Guiyang Integrated Water Resources Master Plan, 2006-2020; and (iii) meet growing demands of water supply fueled by the rapid urbanization. ${ }^{30}$ Since Guizhou is the poorest province in the PRC, the project is a priority to usher socioeconomic development through integrated water resources management in the province's economic hub. The Guiyang Municipal Government is the executing agency for the project.

The current scope of the GIWRMP includes the following components:

(i) establish two medium-sized reservoirs for urban water supply, including dams, water conveyance tunnels, water treatment plants, and transmission pipelines; ${ }^{31}$

(ii) construct six small reservoirs for rural water supply and irrigation;

(iii) rehabilitate and upgrade an irrigation system;

(iv) address soil and water conservation (six subprojects); and

(v) construct small water storage structure (two subprojects).

Among eight reservoirs under the GIWRMP, the Hongyan and Yudongxia reservoirs are medium-sized; the rest are small reservoirs for rural water supply and irrigation for counties and towns.

The Yudongxia Reservoir aims to satisfy the domestic and industrial water demands of Guiyang Municipality. Its major components include the 72-meter high dam, a reservoir with total storage capacity of about 18 million cubic meters, a water treatment plant, and the pipeline networks. The construction of Yudongxia Dam was from 2011 to 2014. Reservoir filling began in June 2014, reaching 1,069 meters in August 2014, its highest level to date. ${ }^{32}$

\footnotetext{
30 Integrated water resources management is a process of managing water, land, forest, and aquatic resources in a river basin context to maximize economic benefits and social welfare in an equitable manner without compromising the sustainability of vital ecosystems (Standing Committee of the Ninth National People's Congress. 2002. Water Law of the People's Republic of China [2002 revision]. http://www.lawinfochina.com/display.aspx?lib=law\&id=2461\&CGid=). It adheres to the following principles: (i) freshwater is a finite and vulnerable resource essential to sustain life, development, and the environment, and should be managed using a holistic approach; (ii) water development and management should be based on a participatory approach involving users, planners, and policy makers at all levels; (iii) women play a central part in the provision, management, and safeguarding of water; and (iv) water has an economic value in all its competing uses and should be recognized as an economic good.

31 A reservoir with a capacity of more than 10.0 to 100.0 million cubic meters $\left(\mathrm{m}^{3}\right)$ is classified as a medium-sized reservoir, and a reservoir with a capacity of 0.1 to 10.0 million $\mathrm{m}^{3}$ is classified as a small reservoir.

32 Based on the design, while the 1,069-meter level has been achieved, the full reservoir supply level is 1,075 meters. Staged reservoir filling is common because it takes several years to stabilize the shoreline.
} 


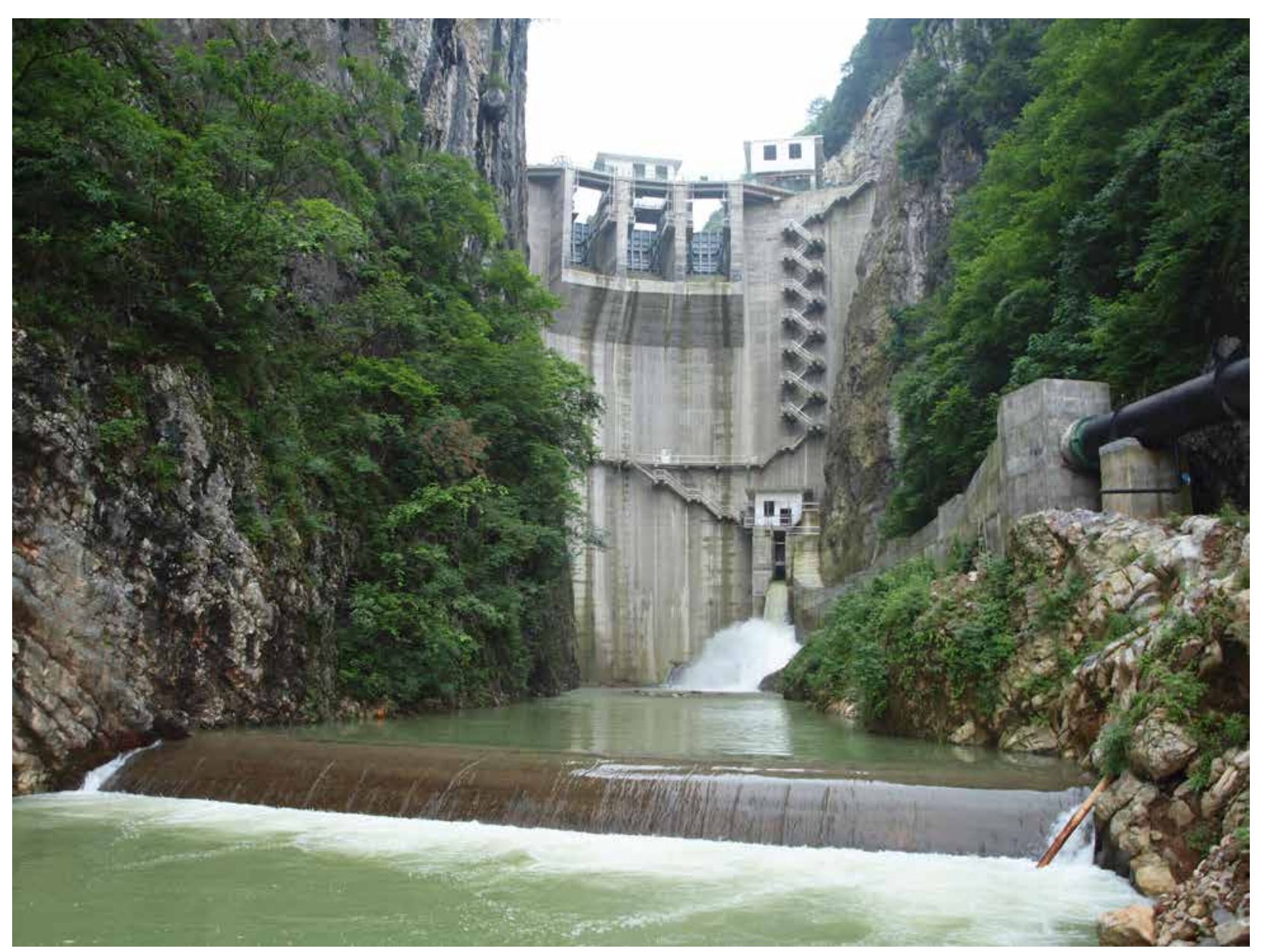

Intake and Downstream Flows from the Yudongxia Dam and Reservoir.

Photo credit: Project Management Office.

Due to the size of the reservoir, Yudongxia's resettlement activities were subject to the State Council Regulations on Land Acquisition Compensation and Resettlement for the Construction of Large- and Medium-Sized Water Conservancy and Hydropower Projects (footnotes 21 and 26) and the PRC's Land Administration Law (footnotes 10 and 19) and other national, provincial, and local regulations. As an ADB-financed project, it was also subject to ADB's Involuntary Resettlement Policy (1995). ${ }^{33}$ Based on national and local regulations, the Guizhou Provincial Government and the Guiyang Municipal Government had considerable experience in developing and implementing medium and large reservoir projects; but, it was a new experience with the ADB policy.

\section{B. Resettlement Scope of Yudongxia Reservoir}

A high dam with a medium-sized reservoir was constructed under the project. It had a wide range of resettlement impacts, including permanent land acquisition, temporary land occupation, physical displacement or house demolition, relocation, and resettlement. The reservoir inundated 19 village groups in 11 villages of 5 townships in 2 districts of Guiyang Municipality and Longli County. The 2006

\footnotetext{
33 ADB. 1995. Policy on Involuntary Resettlement. Manila. https://www.adb.org/documents/policy-involuntary-resettlement
} 
resettlement plan ${ }^{34}$ estimated 1,311 of displaced persons (physically or economically), while the 2012 updated plan estimated 1,620 displaced persons. ${ }^{35}$ The original plan included two resettlement housing sites: one for the Mitangjing group of Ganjing Village, Nanming District; and another for the Xiaoyan groups (Shangjie and Xiajie) of Dayan Village, Longli County. The updated plan included an additional resettlement site for the Shaoshang group of Pianpo Village, Wudang District. These sites were in the same villages, within 1 kilometer of the original houses. While the original plan estimated 53 households for resettlement and the revision estimated 71, the actual number of resettled households was 74 . The reservoir storage level remained the same since the feasibility study report. The difference in the scope of LAR impacts between the updated 2012 plan and actual in 2015 was due to the expanded construction area that included additional stockyards and engineering management stations, and the demolitions of additional structures due to safety reasons. Table 1 summarizes the planned, updated, and actual resettlement impacts.

Table 1: Summary of Resettlement Impacts

\begin{tabular}{lcrrr}
\hline Item & Unit & $\begin{array}{c}\text { RP } \\
\text { (2006) }\end{array}$ & $\begin{array}{c}\text { Updated RP } \\
\text { (2012) }\end{array}$ & $\begin{array}{r}\text { Actual } \\
\text { (2015) }\end{array}$ \\
\hline Total displaced persons (physically or economically) & person & 1,311 & 1,620 & - \\
Physically displaced households & $\mathrm{HH}$ & 53 & 71 & 74 \\
Physically displaced population & person & 212 & 292 & 303 \\
Residential house demolition & $\mathrm{m}^{2}$ & 8,627 & 26,890 & 34,563 \\
Nonresidential demolition & $\mathrm{m}^{2}$ & 4,132 & 3,633 & 4,709 \\
Permanent LA & $m u$ & 3,129 & 2,345 & 2,648 \\
Persons affected by LA & person & 1,311 & 1,620 & - \\
Temporary land occupation & mu & 119 & 116 & 154 \\
Resettlement costs & CNY million & 88 & 356 & 370 \\
\hline
\end{tabular}

$\mathrm{CNY}=$ Chinese yuan, $\mathrm{HH}=$ household, $\mathrm{LA}=$ land acquisition, $\mathrm{m}^{2}=$ square meter, $\mathrm{mu}=\mathrm{a}$ Chinese land measurement $(1 \mathrm{mu}=0.067$ hectares), RP = resettlement plan.

Note: Actual number of displaced persons in 2015 is unavailable as a census was not done since the last RP update.

Sources: Discussions with the project management office staff and the technical assistance consultants in June 2016; Asian Development Bank (ADB). 2006. Yudongxia Reservoir and No. 2 Dongjiao Waterworks Subproject Resettlement Plan. Prepared by the Guiyang Municipal Government for ADB. http://www.adb.org/sites/default/files/project-document/73880/38594-prc-rp.pdf; ADB. 2012. Updated Resettlement Plan for Yudongxia Reservoir Core Subproject. Prepared by the Guiyang Municipal Government for ADB. http://www.adb.org/projects/documents/guiyang-integrated-water-resources-management-sector-project-yudongxiaupdated-rp; ADB. 2014. External Resettlement Monitoring and Evaluation Report (No. 2) for Yudongxia Reservoir and No. 2 Dongjiao Waterworks Subproject. Prepared by the National Research Center for Resettlement, Hohai University, Nanjing, Jiangsu, People's Republic of China (PRC). http://www.adb.org/sites/default/files/project-document/81704/38594-013-smr-02.pdf; ADB. 2015. External Resettlement Monitoring and Evaluation Report (No. 4) for Yudongxia Reservoir and No. 2 Dongjiao Waterworks Subproject. Prepared by the National Research Center for Resettlement, Hohai University, Nanjing, Jiangsu, PRC. http://www.adb. org/projects/38594-013/main\#project-documents; ADB. 2016. External Resettlement Monitoring and Evaluation Report (No. 5) for Yudongxia Reservoir and No. 2 Dongjiao Waterworks Subproject. Prepared by the National Research Center for Resettlement, Hohai University, Nanjing, Jiangsu, PRC. http://www.adb.org/projects/38594-013/main\#project-documents; and ADB. Resettlement PostEvaluation Report for Yudongxia Reservoir and No. 2 Dongjiao Waterworks Subproject. Prepared by the National Research Center for Resettlement, Hohai University, Nanjing, Jiangsu, PRC. Unpublished.

34 ADB. 2006. Yudongxia Reservoir and No. 2 Dongjiao Waterworks Subproject Resettlement Plan. Prepared by the Guiyang Municipal Government for ADB. http://www.adb.org/sites/default/files/project-document/73880/38594-prc-rp.pdf

35 ADB. 2012. Updated Resettlement Plan for Yudongxia Reservoir Core Subproject. Prepared by the Guiyang Municipal Government for ADB. http://www.adb.org/projects/documents/guiyang-integrated-water-resources-management-sectorproject-yudongxia-updated-rp 


\section{Assessment of Impacts and Resettlement Planning}

The Yudongxia Reservoir was conceptualized and studied domestically well before ADB's involvement. In 1998, the Guiyang Municipal Government engaged a provincial design institute to study and develop plans for flood control, water supply, and river course management. The design institute identified the Yudongxia Reservoir as a key water source for the urban area of Guiyang, conducted the feasibility study, and prepared the preliminary design. ${ }^{36}$ During the feasibility study and preliminary design, the design institute compared four reservoir water levels and two possible sites for the waterworks to minimize the LAR impacts. ${ }^{37}$ The design institute decided on an optimum level of 1,075 meters for the reservoir on a site at Tubao Village. It also carefully selected pipeline routes and access roads to minimize farmland occupation, and consulted with local villages, groups, and affected people on the site selection and reservoir inundation area. The ADB-funded project preparatory technical assistance consultants worked with the design institute to prepare the resettlement plan. ${ }^{38}$

In 2008, the design institute also conducted the detailed LAR survey and prepared a detailed resettlement plan. The local government set a cut-off date on 26 August 2008 to cease construction in the reservoir's inundation area. Following the announcement of the cut-off date, the design institute, together with the affected township governments, conducted a detailed measurement survey (DMS) of the LAR impacts. The pre-examination of land use for the Yudongxia Reservoir was approved in March 2009. The design institute completed the detailed resettlement plan in October 2009, which the Guizhou Provincial Resettlement Bureau approved in December 2009. After the preliminary design was approved in 2010, the DMS checks were undertaken together with the affected local governments, villages, and displaced persons during 2010-2011. ${ }^{39}$ The loan implementation consultants assisted in updating the resettlement plan in 2012.

The project did not prepare a separate social impact assessment report. However, the socioeconomic profiles of affected districts, towns, and villages and/or groups; and the LAR impact analysis were all considered when the resettlement plan was prepared. That was the extent of social assessment required for domestic approvals.

The socioeconomic profiles, based on secondary data, included information on population and households, land area and land use, economy and industry, and income. To satisfy the ADB policy requirements, the resettlement plan included results from a survey done on the basic situation of 80 sample affected households and their socioeconomic profiles, including population, gender, age structure, ethnic groups, education level, living space, arable land, household properties, and income and expenditures. In 2012, the external resettlement monitors conducted a comprehensive resettlement baseline study, which was included in their terms of reference. ${ }^{40}$ Table 2 summarizes the chronology in the preparation of the resettlement plan.

The resettlement plan focused on the project's direct physical impacts of LAR. Methods to identify the LAR impacts included a land survey based on maps and on-site measurement by a survey group; census

36 The Guizhou Provincial Government approved the feasibility study report of the Yudongxia Reservoir in 2009 and the preliminary design of the Yudongxia Reservoir in 2010.

37 The design institute studied four water levels between 1,070 meters and 1,085 meters.

38 The consultants also helped to produce an English version of the resettlement plan in 2006.

39 The examination report on the land use was submitted to the Ministry of Land and Resources in September 2011.

${ }^{40}$ ADB. 2014. External Resettlement Monitoring and Evaluation Report (No. 1) for Yudongxia Reservoir and No. 2 Dongjiao Waterworks Subproject. Prepared by the National Research Center for Resettlement, Hohai University, Nanjing, Jiangsu, PRC. https://www.adb.org/sites/default/files/project-document/80156/38594-013-smr-01.pdf 


\section{Table 2: Planning Steps}

\begin{tabular}{ll}
\hline Year & \\
\hline 1998 & The Guiyang Municipal Government engaged a provincial design institute for technical studies. \\
2006 & $\begin{array}{l}\text { The design institute and the consultants of the Asian Development Bank prepared the draft resettlement } \\
\text { plan, including an English version. }\end{array}$ \\
2008 & $\begin{array}{l}\text { The design institute conducted detailed land acquisition and resettlement survey and prepared detailed } \\
\text { resettlement plan. }\end{array}$ \\
2008 & $\begin{array}{l}\text { The local government set the cut-off date, and the design institute undertook the detailed measurement } \\
\text { survey. }\end{array}$ \\
2009 & $\begin{array}{l}\text { The local government approved the pre-examination of land use for the reservoir, and the detailed } \\
\text { resettlement plan was finalized by the design institute and approved by the Guizhou Provincial Resettlement }\end{array}$ \\
& Bureau. \\
2009 & The Guizhou Provincial Government approved the feasibility study report. \\
2010 & The Guizhou Provincial Government approved the preliminary design. \\
2012 & The design institute and local governments did a final check on the detailed measurement survey.
\end{tabular}

Source: Asian Development Bank (ADB). 2014. External Resettlement Monitoring and Evaluation Report (No. 2) for Yudongxia Reservoir and No. 2 Dongjiao Waterworks Subproject. Prepared by the National Research Center for Resettlement, Hohai University, Nanjing, Jiangsu, People's Republic of China (PRC). http://www.adb.org/sites/default/files/project-document/81704/38594-013smr-02.pdf; ADB. 2015. External Resettlement Monitoring and Evaluation Report (No. 4) for Yudongxia Reservoir and No. 2 Dongjiao Waterworks Subproject. Prepared by the National Research Center for Resettlement, Hohai University, Nanjing, Jiangsu, PRC. http://www.adb.org/projects/38594-013/main\#project-documents; ADB. 2016. External Resettlement Monitoring and Evaluation Report (No. 5) for Yudongxia Reservoir and No. 2 Dongjiao Waterworks Subproject. Prepared by the National Research Center for Resettlement, Hohai University, Nanjing, Jiangsu, PRC. http://www.adb.org/projects/38594-013/main\#project-documents; and ADB. Resettlement Post-Evaluation Report for Yudongxia Reservoir and No. 2 Dongjiao Waterworks Subproject. Prepared by the National Research Center for Resettlement, Hohai University, Nanjing, Jiangsu, PRC. Unpublished.

survey of affected households below the inundation and acquisition lines; ${ }^{41}$ survey of special items by competent authorities; and verification of survey results by affected households, village groups, villages, towns, and counties. Individual households signed the verification reports on private assets, while collective organizations signed them for collective properties.

Impact analysis included loss of land; demolition of residential houses and structures; impacts on special facilities; and other impacts, such as the water resource protection zone and downstream irrigation area. ${ }^{42}$ Impact assessments, such as on health, education, food security, social capital, and culture, showed that LAR does not have serious impacts. Relevant social aspects, such as schools, clinics, and administration and recreational centers, were considered in the selection and planning of resettlement sites. ${ }^{43}$ Table 3 presents a summary of assessment of key impacts.

${ }^{41}$ Acquisition line was 1.0 meter above the inundation line for residential houses and 0.5 meter above inundation line for cultivated land.

42 The limit and restriction within the environmental protection zone has not been finalized. However, the concentrated resettlement housing site for the Mitangjing of Ganjing village group was revised due to potential environmental issues. Houses in other sites were relocated in scattered or concentrated manners within the same villages, based on the preference of the affected households.

${ }^{43}$ Reservoir inundation did not have any impact nor did it cause losses to schools, clinics, and administration and recreational centers. There were gathering places for the Buyi community in Xiaoyan of Dayan village groups, and new cultural centers have been constructed at the new resettlement sites. 
Table 3: Summary Assessment of Key Resettlement Impacts

\begin{tabular}{|c|c|}
\hline Impact Types & Step \\
\hline Land acquisition & $\begin{array}{l}\text { Permanent land acquisition affected } 19 \text { village groups within } 11 \text { villages of } 5 \text { townships in } 2 \text { districts } \\
\text { and one county. The area of permanent land acquisition was estimated at } 3,129 \text { mu in the } 2006 \\
\text { resettlement plan, which decreased to } 2,345 \text { mu in the updated resettlement plan based on the } \\
\text { land acquisition and resettlement survey. Permanent land acquisition affected } 456 \text { households in } \\
\text { the updated resettlement plan. Among them, about one-fifth lost more than } 50 \% \text { of land, about } \\
\text { two-fifths lost } 11 \%-50 \% \text { of land, and another two-fifths lost } 10 \% \text { or less. In terms of income loss } \\
\text { due to land acquisition, the affected households from } 9 \text { village groups would lose more than } 10 \% \\
\text { of their net income, among which the affected households in } 4 \text { village groups would lose more } \\
\text { than } 20 \% \text { of their net income. The affected households from the remaining } 10 \text { village groups } \\
\text { would not lose significant income. The affected households losing } 20 \% \text { or more of their net } \\
\text { income were from the following village groups: the Mitangjing of Ganjing Village, Nanming District; } \\
\text { and the Xiaoyan (Shangjie and Xiajie) of Dayan Village, Longli County. }\end{array}$ \\
\hline $\begin{array}{l}\text { Demolition of } \\
\text { residential houses }\end{array}$ & $\begin{array}{l}\text { The } 2006 \text { resettlement plan estimated the demolition of 8,627 square meters of housing area } \\
\text { that would displace an estimated } 53 \text { households. In the updated resettlement plan, the numbers } \\
\text { increased to } 71 \text { households with } 26,890 \text { square meters. Affected residential houses were from the } \\
\text { following village groups: the Mitangjing of Ganjing Village, Nanming District; the Xiaoyan (Shangjie } \\
\text { and Xiajie) of Dayan Village, Longli County; and the Shaoshang of Pianpo Village, Wudang District. } \\
\text { Land acquisition severely affected the first two groups and led to the loss of more than 10\% } \\
\text { income for the third group. }\end{array}$ \\
\hline $\begin{array}{l}\text { Nonresidential } \\
\text { structures, trees, and } \\
\text { special facilities }\end{array}$ & $\begin{array}{l}\text { Impacts on nonresidential structures included damages to two properties (scenic spots) of } \\
\text { Yudongxia Company with related tourism revenue losses and a collective house. Impacted } \\
\text { structures included } 459 \text { tombs, } 8.25 \text { kilometers of tractor road, } 1 \text { power substation, } 5 \text { pumping } \\
\text { stations, } 26.02 \text { kilometers of canals, } 14 \text { pedestrian bridges, and } 20 \text { spill-weirs. More than 50,000 } \\
\text { scattered trees were also affected. }\end{array}$ \\
\hline Other impacts & $\begin{array}{l}\text { Other potential impacts included a water source protection zone and downstream irrigation } \\
\text { water use. Since Yudongxia Reservoir is for domestic water supply, it requires an environmental } \\
\text { protection zone above the reservoir where certain activities are restricted. The updated } \\
\text { resettlement plan included a first-class protection zone of } 6.08 \text { square kilometers and second- } \\
\text { class protection zone of } 17.46 \text { square kilometers where house construction and certain agricultural } \\
\text { activities are unrestricted. However, the environmental protection zone has not been fully } \\
\text { implemented. The existing water use downstream included } 2,952 \text { mu of irrigated farmland (mostly } \\
\text { for vegetables) by } 3,377 \text { people. The existing water off-take will be maintained by restoring the } \\
\text { facilities; and so, negative impacts are not expected in this respect. In fact, most of these areas are } \\
\text { being lost to urbanization, and the irrigation demand is decreasing. }\end{array}$ \\
\hline
\end{tabular}

a In 2009, Yongle Town was transferred from Wudang to Nanming for administrative reasons.

b Affected persons built new houses from 2006 to 2012.

Source: Discussions with the project management office staff and the technical assistance consultants in June 2016; Asian Development Bank (ADB). 2014. External Resettlement Monitoring and Evaluation Report (No. 2) for Yudongxia Reservoir and No. 2 Dongjiao Waterworks Subproject. Prepared by the National Research Center for Resettlement, Hohai University, Nanjing, Jiangsu, People's Republic of China (PRC). http://www.adb.org/sites/default/files/project-document/81704/38594-013-smr-02.pdf; ADB. 2015. External Resettlement Monitoring and Evaluation Report (No. 4) for Yudongxia Reservoir and No. 2 Dongjiao Waterworks Subproject. Prepared by the National Research Center for Resettlement, Hohai University, Nanjing, Jiangsu, PRC. http://www.adb. org/projects/38594-013/main\#project-documents; ADB. 2016. External Resettlement Monitoring and Evaluation Report (No. 5) for Yudongxia Reservoir and No. 2 Dongjiao Waterworks Subproject. Prepared by the National Research Center for Resettlement, Hohai University, Nanjing, Jiangsu, PRC. http://www.adb.org/projects/38594-013/main\#project-documents; and ADB. Resettlement PostEvaluation Report for Yudongxia Reservoir and No. 2 Dongjiao Waterworks Subproject. Prepared by the National Research Center for Resettlement, Hohai University, Nanjing, Jiangsu, PRC. Unpublished. 


\section{Consultation, Participation, and Grievance Redress Mechanism}

The project's measures for consultation and participation aimed to (i) solicit opinions and suggestions from the affected households and (ii) reduce grievances and disputes during the preparation and implementation of the resettlement plan. During project preparation, socioeconomic surveys and public consultations helped in preparing the resettlement plan. Local governments and the design institute had conducted public consultation activities in the affected villages to disseminate project information and get feedback on resettlement and livelihood restoration measures. The draft resettlement plan was disclosed to groups of the affected households through information booklets describing compensation rates, the grievance redress mechanism, etc. Measures ensuring public participation during implementation included:

(i) land acquisition announcements through village bulletin boards and village meetings to disclose land acquisition areas, compensation rates, and resettlement schemes;

(ii) dissemination of compensation and resettlement options to the affected households;

(iii) verification of the DMS results through field survey with the affected households;

(iv) meetings with village leaders and affected households to discuss income restoration plans and training programs;

(v) finalization of resettlement site plans and development through village meetings and discussions with village leaders and affected households; and

(vi) participation of villagers and affected households in resettlement implementation and monitoring.

A grievance redress mechanism comprising four steps received and resolved grievances. Resettlement information bulletins and mass media informed affected villages about the mechanism. Grievances received were resolved locally, except for some cases involving land ownership, which needed interventions at higher levels.

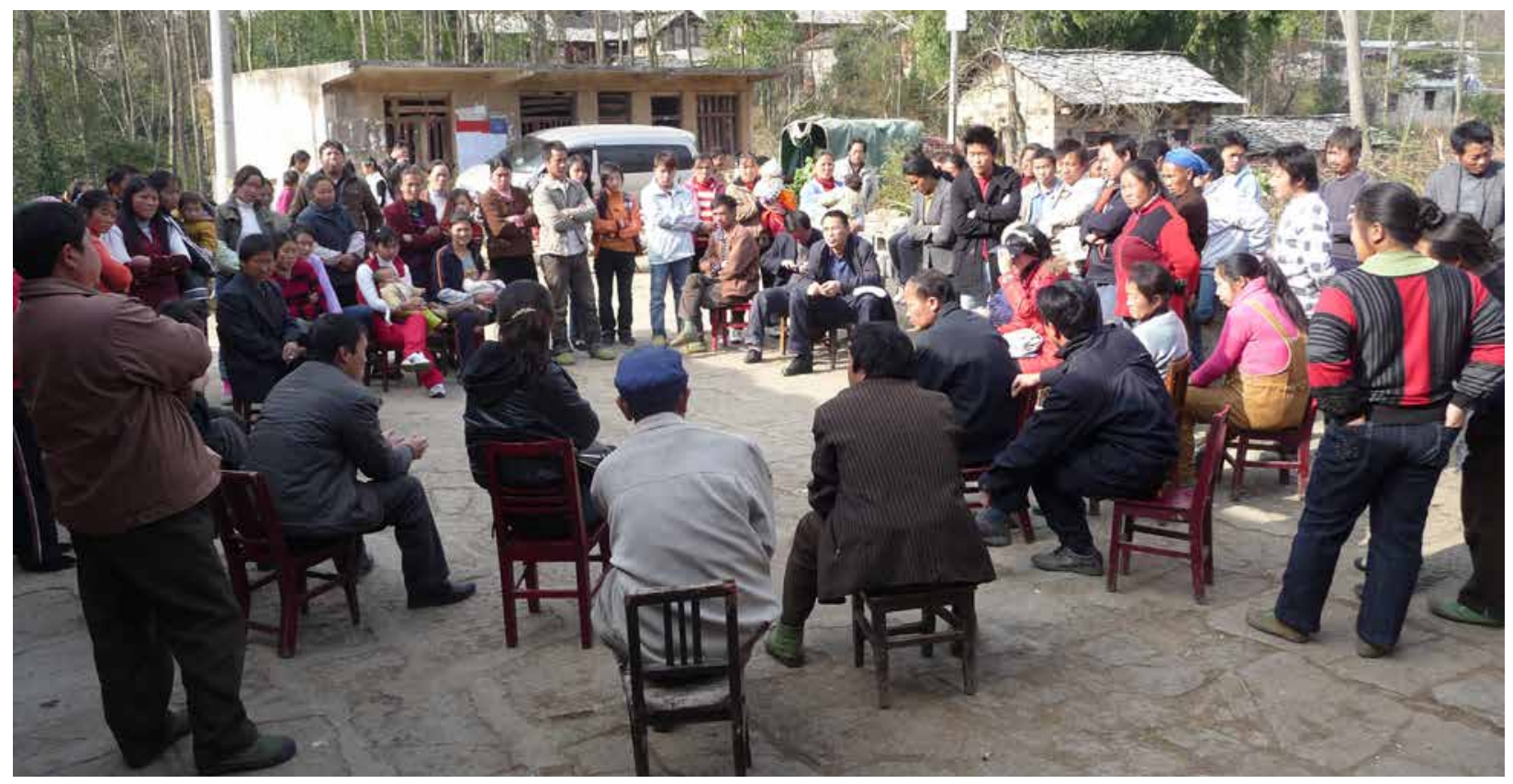

A Stakeholder Meeting in the Project Area.

Photo credit: Scott Ferguson. 


\section{E. Compensation, Resettlement, and Rehabilitation Measures}

The project's resettlement and rehabilitation objective was to ensure the restoration and improvement of the income and standards of living of displaced persons after resettlement. This included restored agricultural production and income; and an equal or better public infrastructure, transport, education and medical facilities, social welfare, and natural environment. The project's principles were to respect the willingness and ethnic traditions of displaced persons to (i) match the impacts to rehabilitation programs combined with overall development and environmental protection, and (ii) improve the standards of vulnerable groups.

Local governments adopted and implemented a range of compensation, resettlement, and rehabilitation measures in the resettlement plan to restore or improve the living standards of displaced persons. Resettlement and rehabilitation approaches differed for seriously and slightly affected households. Among the affected groups, the Mitangjing, Shaoshang, and Xiaoyan (Shangjie and Xiajie) groups were seriously affected. All slightly affected households preferred cash compensation and wanted to use it for crop restructuring and stockbreeding. Detailed resettlement and rehabilitation plans were prepared for the affected households in the seriously affected groups. The plans included measures for house and infrastructure construction at resettlement sites; production and income restoration; support to women, ethnic minorities, and vulnerable groups; recovery of affected infrastructures; and postresettlement support.

The following were the measures discussed, which were grouped based on the sustainable developmental resettlement perspective.

\section{House and Community Reconstruction}

The measures for affected households who lost their residential houses included cash compensation at replacement cost for demolished houses, compensation for public infrastructure, and moving subsidy. The affected nonresidential structures were compensated at replacement cost, and compensation was provided for losses of businesses and wages. All displaced households preferred moving back within the village group. The affected groups had a choice between scattered and concentrated resettlement. Under concentrated resettlement, village committees provide housing sites, local governments provide infrastructure, and displaced persons construct their own houses. Under scattered resettlement, displaced persons select the sites (with the approval of the village committee), develop their own infrastructure services, and construct their own houses. Among the 74 displaced households, 33 opted for scattered resettlement and 41 for concentrated resettlement. Affected houses were demolished in 2013. By 2014, 71 affected households completed their new houses, while two more completed their houses by $2015 .{ }^{44}$ Though the affected households received all house compensation payments before the displacement, some stayed in temporary accommodation due to delays in the construction of their homes. All new resettlement sites have improved public facilities, such as roads, electricity, water supply, sewers, and drainage.

\footnotetext{
${ }^{44}$ All eight affected households of the Shaoshang group in Wudang District constructed new houses by January 2014. All 36 affected households of Xiaoyan groups in Longli County constructed houses by December 2014. Of the 30 affected households of Mitangjing group in Nanming District, 27 affected households constructed houses by December 2014; another 2 affected households constructed houses by December 2015; and 1 affected household did not construct a new house because they intend to move elsewhere (i.e., Guiyang City).
} 


\section{Land Compensation, Restoration of Production, and Employment}

The measures for affected households who lost land included cash compensation for land and crops, skills training for agricultural production and nonfarm employment, and land-loss farmers' endowment premiums ${ }^{45}$ Rather than readjusting land within affected villages, cash compensation was a better option because all lands within the village were already contracted, and there was not enough cultivated land left for readjustment. Further, with their own ideas on sources of income, affected farmers preferred cash compensation. Land acquisition and compensation were completed, except for a few parcels where ownership disputes are still being resolved. Agricultural skills and nonagricultural vocational trainings were available to displaced persons to improve their income-generating capacity. The trainings covered fish culture, forest and fruit cultivation, farm machinery repair, hairdressing, embroidery, and handicrafts. The crop-restructuring measures included shifting cultivation from paddy and corn to more vegetables and fruits (peach, waxberry, etc.) and stockbreeding. Farmers willing to work in towns had access to skills training and employment assistance. However, only the older generation of the affected population still engages in agriculture. Younger men prefer construction work, while younger women work in the service sector. Overall, affected households have become more interested in nonagricultural work, and they have become increasingly dependent on daily wages and remittances. An estimated three-fourths of the 2015 annual income of affected households came from nonagricultural sources. This trend is likely to continue or even increase given that affected villages are in suburb areas of Guiyang City. Based on the external resettlement monitor's postresettlement income survey, the average household net income of affected households in 2015 was CNY65,640, which was higher than the average household net income of CNY49,160 in 2011. Accounting for inflation since 2011, the real average household income of 2015 (in 2011 price) would be CNY57,730, which is 17\% higher than the 2011 income.

\section{Restoration of Community Assets, Cultural Resources, and Living Environment}

The recovery plan included reconstruction of water and power supplies, irrigation pumping stations, sewers, drainage, and other community infrastructure. The plan is mostly completed. Reconstructed village roads improved access to social services and markets. Irrigation water from new pumping stations is expected to promote fruit and vegetable cultivation. The local government constructed two ethnic cultural squares, making it convenient for the local Miao and Buyi ethnic minorities to carry out ethnic celebrations. Tourism training was provided, and some households started restaurant businesses. ${ }^{46}$ Better infrastructure and management of solid waste and wastewater should improve the local living environment in resettlement sites.

\section{Social Inclusion and Empowerment}

Measures to empower women, ethnic minorities, and vulnerable groups focused on skills training and targeted unskilled jobs during local infrastructure construction. During civil works construction, 90 local persons were employed. A special fund for the vulnerable groups helped form a disabled association in Toubao Village, provide livelihood support to vulnerable households in Pianpo Village, and give consolation grants to old people in Housuo. In addition, registered rural adult residents are eligible for

45 Under the PRC regulations, if land size becomes less than $0.3 \mathrm{mu}$ per capita and the male farmer is 60 years old and the female farmer is 55 years old, they can receive endowment insurance. Younger adults are eligible to enroll in the insurance program. In this project's case, funds have been paid into a special account of the Labor and Social Affairs Department of Guizhou.

46 Tourism activities are small scale at community level and are not expected to be noncompliant of the Yudongxia Reservoir's water quality requirements, although local governments need to monitor these activities. 


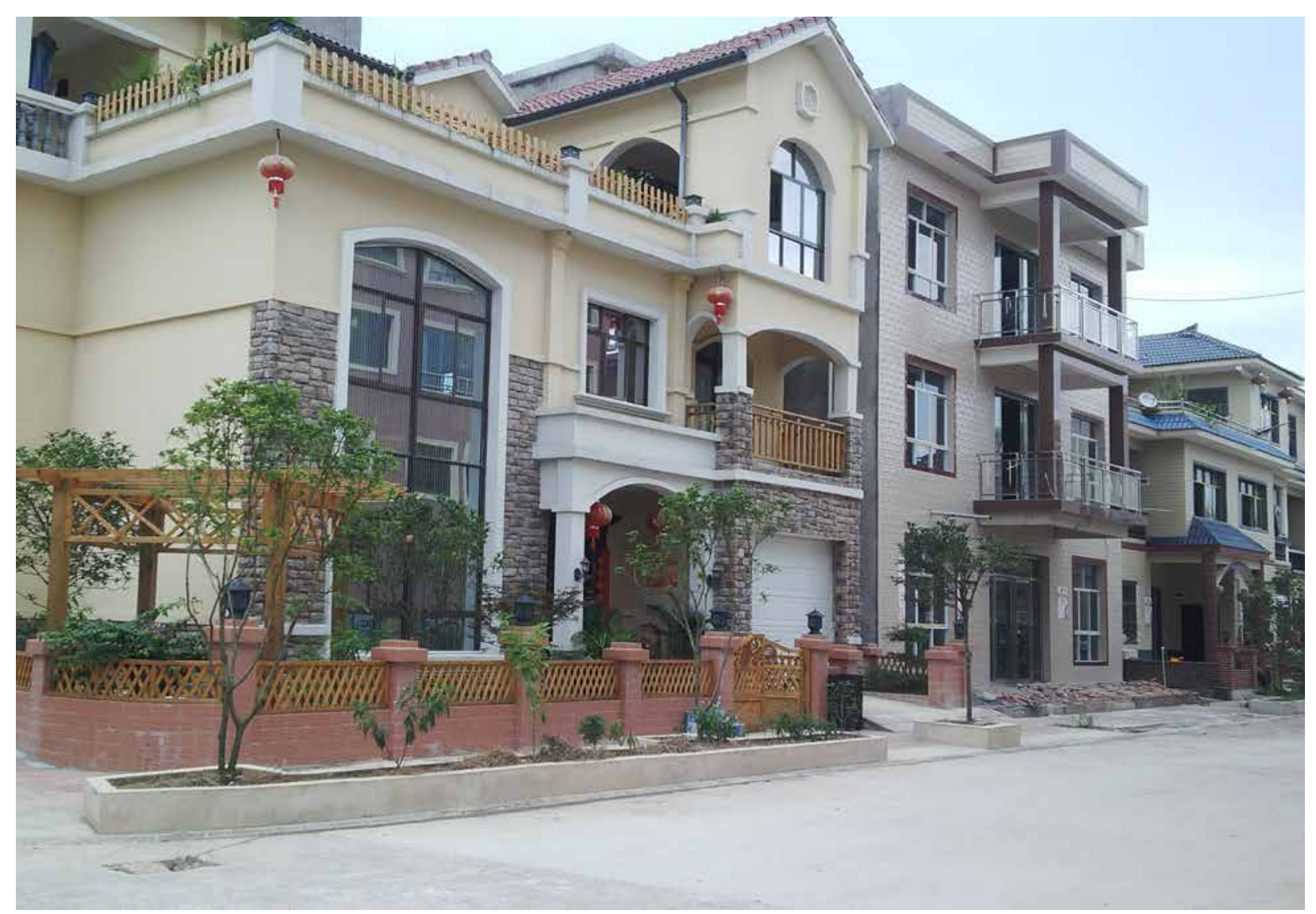

New Houses in Resettlement Site.

Photo credit: Nogendra Sapkota.

insurance, based on the measures on rural social endowment insurance of Guiyang City. The Ministry of Water Resources approved quotas for postresettlement support to affected households in January 2016, and quarterly payments started in the same year.

\section{Health and Education Services}

Nearby communities had access to health services to help control the spread of infectious diseases. Patients from affected villages received medical assistance. A health education program was carried out in the project area during the project construction. Local health departments continue providing health services to resettled communities. Solid waste transfer stations in resettlement sites improved health and sanitation conditions. Schools were not inundated, and displaced groups were resettled nearby; thus, children of affected households have continued access to education.

Table 4 summarizes the measures in the resettlement plan and their implementation status. 
Table 4: Compensation and Resettlement Measures

\begin{tabular}{|c|c|c|}
\hline Impact Types & Measures in the Resettlement Plan & Implementation Status \\
\hline \multirow[t]{3}{*}{ Land acquisition } & $\begin{array}{l}\text { Land compensation fees, resettlement subsidies, } \\
\text { compensation of young crops (cultivated land } \\
\text { CNY34,500-CNY99,000 per mu; other lands } \\
\text { CNY4,500-CNY39,600 per mu) }\end{array}$ & $\begin{array}{l}\text { Land compensation fees, resettlement subsidies, } \\
\text { and compensation of young crops paid ( } 99 \% \\
\text { completed) }\end{array}$ \\
\hline & Priority in unskilled jobs (350 person-years) & $\begin{array}{l}\text { At least } 90 \text { local laborers employed during } \\
\text { construction }\end{array}$ \\
\hline & A special fund for skills training (CNY65,000) & $\begin{array}{l}\text { Skills training provided, and affected persons } \\
\text { assisted to find jobs. }\end{array}$ \\
\hline \multirow[t]{6}{*}{ House demolition } & $\begin{array}{l}\text { Compensation at replacement cost } \\
\text { (CNY486-CNY706 per square meter) }\end{array}$ & Affected households received compensation. \\
\hline & Centralized or scattered relocation & $\begin{array}{l}\text { Of } 74 \text { affected households, } 73 \text { have new houses. } \\
\text { All } 8 \text { affected households in Shaoshang group in } \\
\text { Wudang District have new houses under scattered } \\
\text { resettlement. Of } 36 \text { affected households in } \\
\text { Xiaoyan groups in Longli County, } 12 \text { have new } \\
\text { houses under scattered resettlement, and } 24 \text { have } \\
\text { new houses under concentrated resettlement. } \\
\text { Of } 31 \text { affected households in Mitangjing group } \\
\text { in Nanming District, } 17 \text { have new houses } \\
\text { under concentrated resettlement, } 13 \text { affected } \\
\text { households have new houses under scattered } \\
\text { resettlement, and } 1 \text { relocated on their own } \\
\text { elsewhere. }\end{array}$ \\
\hline & $\begin{array}{l}\text { Compensation for public infrastructure, including } \\
\text { housing site, land leveling, water and power, } \\
\text { streets, sewerage, etc. }\end{array}$ & $\begin{array}{l}\text { Compensation for infrastructure provided, and } \\
\text { infrastructure built by local governments in } \\
\text { concentrated resettlement sites. }\end{array}$ \\
\hline & Moving subsidy & \\
\hline & Insurance premiums & \\
\hline & $\begin{array}{l}\text { Postresettlement support } \\
\text { (CNY600/person/year for } 20 \text { years) }\end{array}$ & $\begin{array}{l}\text { The Ministry of Water Resources approved } \\
\text { affected households' quotas for postresettlement } \\
\text { support in January 2016, and payments are made } \\
\text { quarterly since } 2016 \text {. }\end{array}$ \\
\hline \multirow{5}{*}{$\begin{array}{l}\text { Loss of } \\
\text { nonresidential } \\
\text { structures }\end{array}$} & Compensation at replacement cost & \multirow{2}{*}{$\begin{array}{l}\text { Compensation completed for nonresidential } \\
\text { structure and businesses. Each business decides } \\
\text { how to invest the funds. Recreational activities at } \\
\text { the foot of the dam continue. }\end{array}$} \\
\hline & Compensation for business losses & \\
\hline & Compensation of wage losses for employees & \multirow{3}{*}{$\begin{array}{l}\text { Those that lost jobs at Jinlong Valley received } \\
\text { subsidies. }\end{array}$} \\
\hline & Free training & \\
\hline & Employment information & \\
\hline Special facilities & Compensation at replacement cost & $\begin{array}{l}\text { Affected facilities in Longli, Nanming, and } \\
\text { Wudang compensated or reconstructed. }\end{array}$ \\
\hline
\end{tabular}


Table 4 continued

\begin{tabular}{|c|c|c|}
\hline Impact Types & Measures in the Resettlement Plan & Implementation Status \\
\hline \multicolumn{3}{|l|}{ Other Impacts: } \\
\hline \multirow{3}{*}{$\begin{array}{l}\text { Vulnerable } \\
\text { groups-specific }\end{array}$} & Occupational training & \multirow{3}{*}{$\begin{array}{l}\text { One affected household member could not } \\
\text { attend training nor gain employment due to old } \\
\text { age. Local government provided free new housing } \\
\text { Activities conducted in relevant villages for } \\
\text { vulnerable people. }\end{array}$} \\
\hline & Priority employment & \\
\hline & Special support fund (CNY1,000/person) & \\
\hline \multirow[t]{2}{*}{ Women-specific } & Priority in employment & \multirow{2}{*}{$\begin{array}{l}\text { Women and ethnic minority households } \\
\text { participated in training and employment. }\end{array}$} \\
\hline & Priority in agricultural training & \\
\hline \multirow{3}{*}{$\begin{array}{l}\text { Ethnic minorities- } \\
\text { specific }\end{array}$} & Priority in employment & \multirow[t]{2}{*}{ Training and jobs were provided. } \\
\hline & Priority in agricultural training & \\
\hline & Reconstruct cultural squares & Cultural squares were constructed. \\
\hline
\end{tabular}

CNY = Chinese yuan, $m u=a$ Chinese land measurement $(1 \mathrm{mu}=0.067$ hectares $)$.

Sources: Discussions with the project management office staff and the technical assistance consultants in June 2016 and visits to resettlement sites; Asian Development Bank (ADB). 2014. External Resettlement Monitoring and Evaluation Report (No. 2) for Yudongxia Reservoir and No. 2 Dongjiao Waterworks Subproject. Prepared by the National Research Center for Resettlement, Hohai University, Nanjing, Jiangsu, People's Republic of China (PRC). http://www.adb.org/sites/default/files/project-document/81704/38594013-smr-02.pdf; ADB. 2015. External Resettlement Monitoring and Evaluation Report (No. 4) for Yudongxia Reservoir and No. 2 Dongjiao Waterworks Subproject. Prepared by the National Research Center for Resettlement, Hohai University, Nanjing, Jiangsu, PRC. http://www.adb.org/projects/38594-013/main\#project-documents; ADB. 2016. External Resettlement Monitoring and Evaluation Report (No. 5) for Yudongxia Reservoir and No. 2 Dongjiao Waterworks Subproject. Prepared by the National Research Center for Resettlement, Hohai University, Nanjing, Jiangsu, PRC. http://www.adb.org/projects/38594-013/main\#project-documents; and ADB. Resettlement Post-Evaluation Report for Yudongxia Reservoir and No. 2 Dongjiao Waterworks Subproject. Prepared by the National Research Center for Resettlement, Hohai University, Nanjing, Jiangsu, PRC. Unpublished.

\section{F. Resettlement and Rehabilitation Measures for Seriously Affected Groups}

\section{Mitangjing Group in Nanming District}

The Mitangjing in Nanming District had 81 affected households, including 31 households with house demolition. About two-thirds of the group's cultivated land was acquired. Average per capita cultivated land after land acquisition was $1.32 \mathrm{mu} .{ }^{47}$ The remaining lands provided an option to affected households to continue farming, including economic crops (e.g., orchards, vegetables). While the older generation of affected households still farm, younger displaced persons are more interested in nonagricultural employment opportunities resulting from the expansions of Guiyang City and nearby towns.

Affected households from this group that needed relocation and resettlement preferred to move back within the village. The initial plan was to provide a concentrated resettlement site by the village committee, 300 meters away from the former settlement, to house all affected households. However, during implementation, the planned resettlement site was within the environmental protection zone. Consequently, 17 houses were built under concentrated resettlement at a new site, and 13 houses were built under scattered resettlement closer to the main village. All affected households have since moved to their new homes.

\footnotetext{
47 Affected villages also had other remaining land, including forestland.
} 


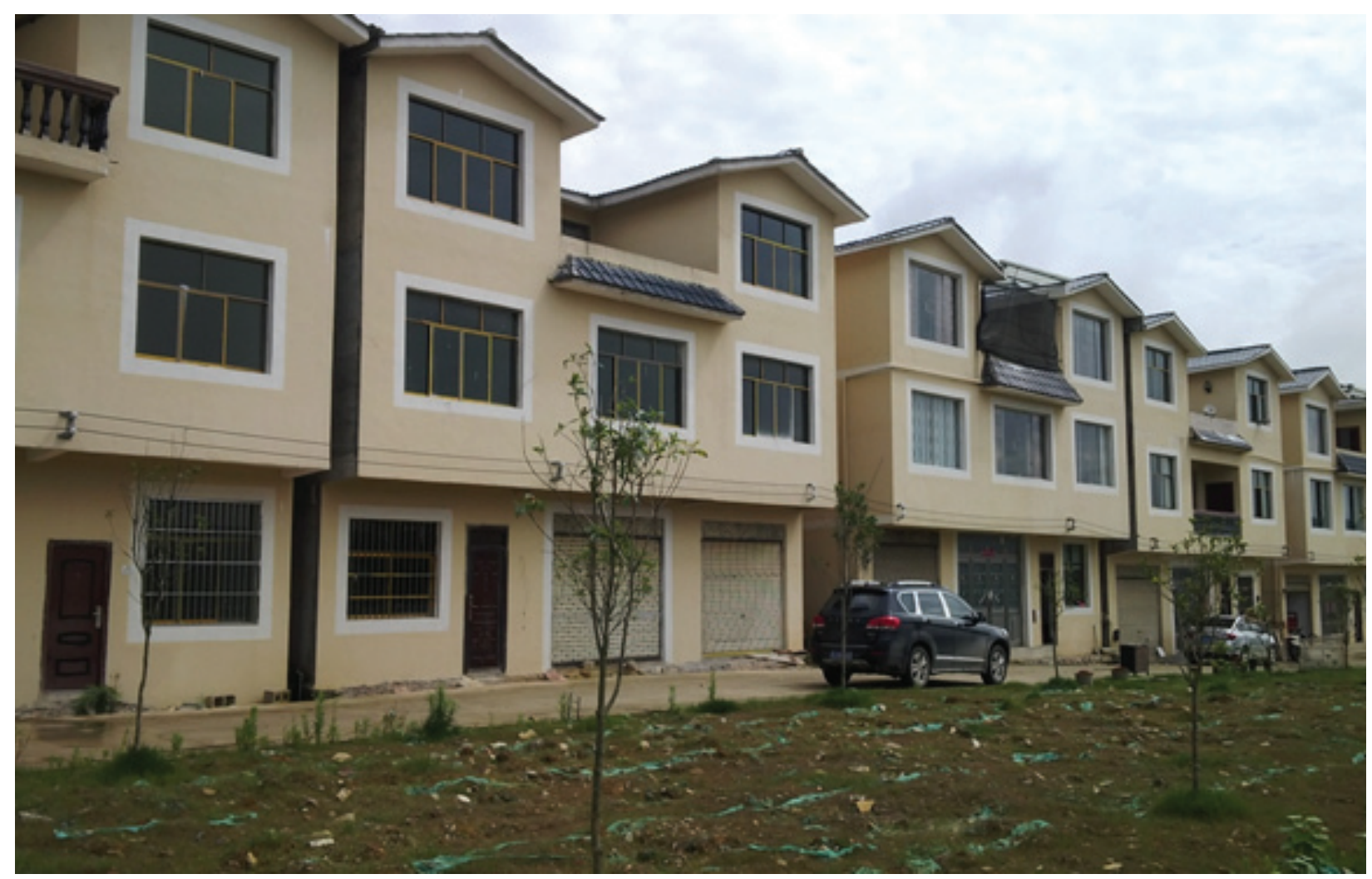

New Houses of Mitangjing Group in Nanming District.

Photo credit: Asian Development Bank.

Local governments constructed infrastructure and public facilities at the concentrated resettlement site, including access roads, water and power supplies, and sewers. For scattered resettlement, the affected groups had to arrange new sites themselves using compensation funds for the affected infrastructure. Since both concentrated and scattered resettlement sites are nearby, affected households have continued access to social services, such as school, health center, and village offices.

The production and income restoration measures included crop restructuring and employment. Crop restructuring was expected to improve land productivity and replace paddy and corn with higher-value vegetable crops. Plantation of fruit trees was planned on an average of $1 \mathrm{mu}$ per capita on barren hills and grass slopes. Affected households received skills training on agriculture, marketing, etc. A business startup road show for affected households provided knowledge to start their own businesses. New roads and irrigation pumps are expected to increase agricultural production and market value for affected households. However, as stated elsewhere, while elderly people remain in agriculture and continue farming, most people want nonagricultural work in towns and cities. Majority of affected household income comes from employment and other nonfarm sources.

\section{Xiaoyan Groups (Shangjie and Xiajie) in Longli County}

The Shangjie and Xiajie groups in Longli County had 65 affected households, including 36 that are requiring house demolition. About half of the groups' cultivated land was acquired. Average per capita cultivated land after land acquisition was $2.23 \mathrm{mu}$. 


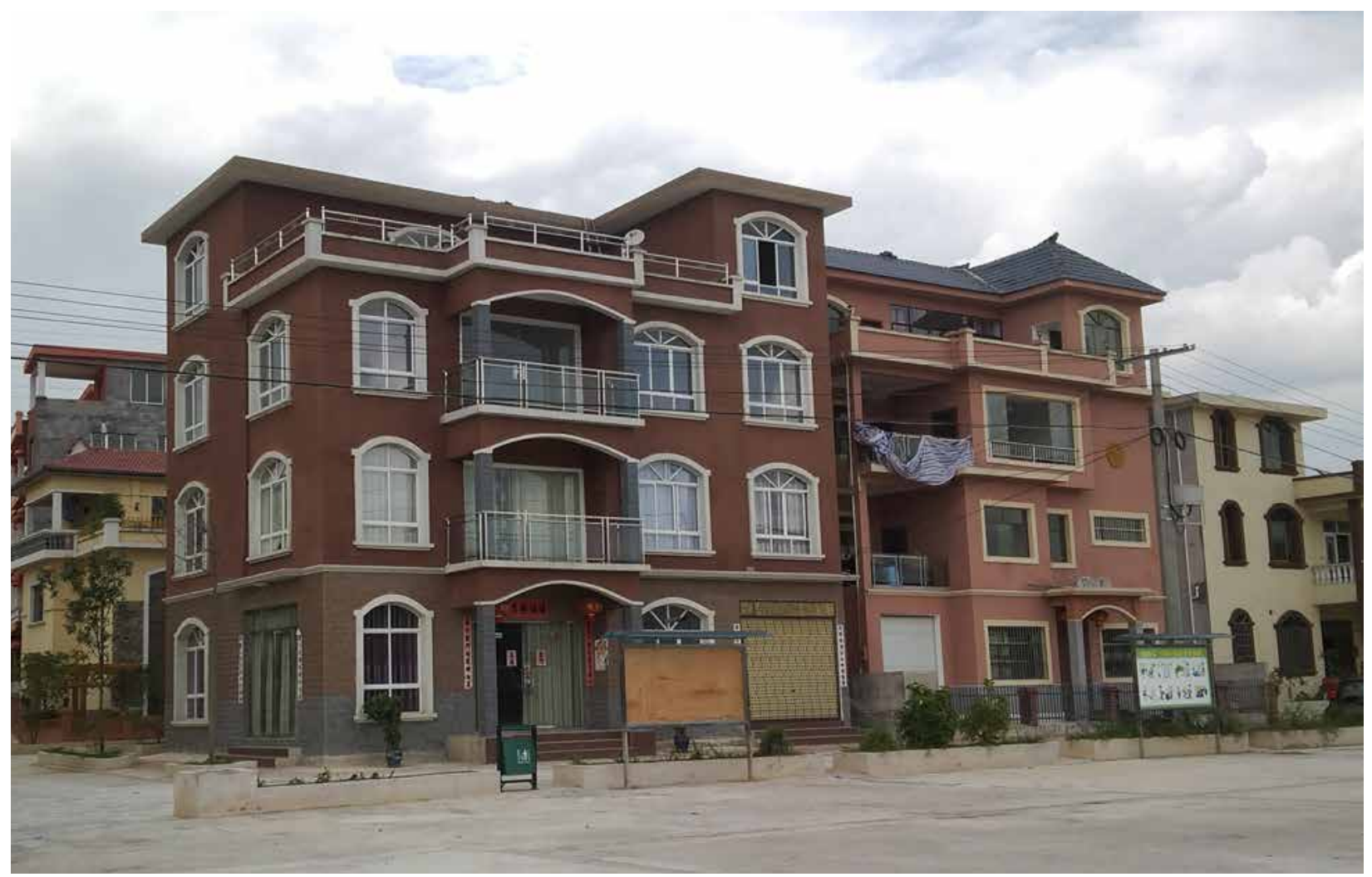

New Houses of Xiaoyan Groups in Longli County.

Photo credit: Nogendra Sapkota.

All affected households requiring physical resettlement in these groups also preferred to move back within the village in a resettlement site located beside a Class-4 highway between Guiyang and Pianpo villages. It is accessible to social services, such as schools. All affected households have moved to their new houses, of which 24 affected households are in concentrated resettlement, and 12 in scattered resettlement. Many of these new homes are much larger and of better quality than the original houses.

Local governments constructed infrastructure and public facilities at the concentrated resettlement site. Affected groups arranged their own sites under scattered resettlement. Since resettlement sites are not far from existing social services, such as school, clinic, and administrative building, they have continued access to such services. A cultural area for affected households to gather and have festivals replaced the simple public area that they had before.

The production and income restoration measures for these groups also included crop restructuring and employment. Crop restructuring aimed to replace grain crops with high-value vegetable crops. The plantation of fruit trees aimed to grow peach, waxberry, and grape. There is now an irrigation pumping system to supply water for farmland and fruit cultivation. Livestock pens for stockbreeding were completed. Skills training on tourism, for example, were provided. However, like the Mitangjing group, agriculture-based income restoration measures for the Xiaoyan groups are difficult because most people prefer nonagricultural employment, which now generates the majority of the affected household's income. 


\section{Shaoshang Group in Wudang District}

The Shaoshang group had 13 affected households, including 8 that required house demolition. The land acquisition only caused a per capita loss of $0.12 \mathrm{mu}$ of cultivated land. Affected households who lost cultivated land received one-time cash compensation. All eight affected households built houses under scattered resettlement. The township government helped to construct houses and provided medical assistance to a vulnerable household. The local Miao and Buyi people now have an ethnic cultural square.

In conclusion, among the seriously affected groups, the construction of new houses and infrastructure facilities is almost complete. The quality of the new houses is much better than the old ones. Since the new houses are within the affected villages, affected households have continued access to existing social services, such as health and education. The sites have convenient transport services, which would benefit people who work outside or sell goods to markets. Skills trainings were conducted, and affected households were expected to invest their compensation in cash crops, stockbreeding, etc. However, most people prefer work outside of agriculture, so the majority of the affected household's income is now from employment. The external resettlement monitor's postresettlement income survey shows that the household net income of affected households in 2015 was 17\% higher than the 2011 income after adjusting the inflation.

\section{G. Resettlement Monitoring and Evaluation}

Monitoring provisions for Yudongxia included both internal and external monitoring. The project management office, with relevant local governments, conducted internal monitoring on regular LAR activities. An independent agency, Hohai University, was responsible for external monitoring and evaluation. The external monitoring evaluated outcomes of resettlement as well as periodic monitoring of implementation of the resettlement plan. The external monitor has so far produced five monitoring reports, which mainly focused on the delivery of compensation and physical resettlement of affected households, and a draft postresettlement evaluation report.

\section{CONCLUSION}

The following conclusion can be drawn from the study of conceptual frameworks, reservoir resettlement policies and practices in the PRC, and the Yudongxia Reservoir experience:

\section{A. Conceptual Framework}

Involuntary resettlement is a complex issue and requires a comprehensive framework to study and manage, particularly in reservoir resettlement. Most frameworks focus on analysis or prediction of adverse impacts or risks arising from involuntary resettlement. Some development-oriented resettlement frameworks also focus on counter-risk or rehabilitation strategies. The sustainable developmental resettlement framework provides a comprehensive tool to assess, plan, and monitor resettlement programs.

The conceptual framework of sustainable developmental resettlement that the authors synthesized and presented in Chapter 2 includes a wide range of variables, including a set of ten impoverishment risks and a similar number of rehabilitation measures to ensure sustainable development outcomes for displaced persons. The study confirms that the framework is useful in evaluating resettlement impacts and rehabilitation measures. However, it also reveals that impacts and rehabilitation measures do not 
uniformly apply across all situations. For example, Yudongxia had low-level impacts in terms of loss of education, health, and social capital; while, impacts in terms of loss of residential houses were significant, and the resettlement measures included better and sustainable housing for displaced persons. In addition, retaining a portion of farmland and giving the option to resettle within the same village avoided or reduced many risks. This suggests that, since impacts and required rehabilitation measures vary across situations, the framework should be applied flexibly.

\section{B. National Context of Reservoir Resettlement Policies}

The national and local resettlement policies, practices, and institutional capacity play an important role in determining the land acquisition and resettlement (LAR) outcomes of reservoir projects. The PRC era of reservoir construction started in the late 1950s, and resettlement results were problematic in the first 2 decades. Several amended legislations, including the Land Administration Law (footnotes 10 and 19) and the Regulations on Land Acquisition Compensation and Resettlement for the Construction of Large- and Medium-Sized Water Conservancy and Hydropower Projects (footnotes 21 and 26) that have been enacted and implemented since the mid-1980s, continue to improve. The Yudongxia Reservoir, which was developed in the beginning of 2000s, had to comply with the improved domestic legislations and the ADB Policy on Involuntary Resettlement (footnote 33). Also, since it was a period of economic boom for the PRC, there were many options for livelihood restoration. This provided a good policy context to the planning and implementation of resettlement program for the Yudongxia Reservoir.

\section{Yudongxia Reservoir Case Study}

\section{Assessment of Resettlement Impacts and Preparation of the Resettlement Plan}

It is important to study various project and design alternatives and select a most appropriate option that has the least adverse social impacts. Accurately identifying displaced persons and adequately assessing potential social impacts and risks are vital for resettlement planning. The Yudongxia case shows that during the feasibility study and preliminary design, the project adopted measures, including the comparison of different reservoir water levels and adoption of optimum water level, to minimize LAR. The local geography is mountainous, and the dam inundates a gorge for the first 5 kilometers; and then, the landscape is relatively flat with some low-lying farmland. Choosing a dam height higher than 1,075 meters would have caused significantly more farmland loss, so the selected dam height of Yudongxia minimized the LAR impacts. As a result, it did not inundate complete villages; and existing village infrastructure, agricultural production, and social networks were not destroyed. LAR impacts and affected households were identified during the feasibility study report and included in the draft resettlement plan. After the detailed LAR survey, the updated resettlement plan incorporated the updated information. While Yudongxia did not follow a specific theoretical model to assess social impacts and a separate social impact assessment report was not prepared, resettlement plan preparation included socioeconomic profiles of displaced persons, including a sample socioeconomic survey and an analysis of the LAR impacts.

\section{Consultation, Participation, and Grievance Redress}

These are very important social aspects during the LAR planning and implementation. Not only do these increase the success of the resettlement program but they also minimize conflicts, implementation delays, and costs due to conflicts and delays of reservoir projects. Consultation and participation measures for the Yudongxia Reservoir included social surveys and public consultations during the preparation of the resettlement plans. Consultation meetings and communications with affected villages were carried 
out during the resettlement plan implementation and monitoring. An established grievance redress mechanism resolved grievances locally, except for a few land ownership disputes that are pending. Extensive consultation and participation measures at the planning stage must continue throughout the project cycle to ensure sustainable resettlement outcomes. Aside from the many details that are only worked out during implementation, unexpected issues may also arise; and, these should be addressed together with affected households.

\section{Managing Resettlement Impacts to Achieve Sustainable Development Outcomes for Displaced Persons}

Managing resettlement impacts is as critical as managing the project's technical and other aspects to achieve sustainable development outcomes. The resettlement plan for Yudongxia comprised comprehensive compensation, resettlement, and rehabilitation measures, including (i) cash compensation, skills training, production restoration, and livelihood support for affected households who lost land; and (ii) cash compensation, concentrated and scattered resettlement, and livelihood support for displaced persons requiring relocation. Priority employment and vocational training for women and ethnic minorities were targeted measures. The study reveals that compensation and resettlement measures were successful, while livelihood measures still have mixed results. The following are key conclusions:

(i) House and community reconstruction was relatively successful. The construction of houses and facilities is complete for all three village groups that required relocation. All affected households have new houses with better quality and access to public services. Some affected households had to stay in temporary accommodations before they moved to new houses due to delays in finalization of resettlement sites and construction of new houses. There is a need to further improve resettlement planning, implementation, and coordination to make sure resettlement sites are fully constructed prior to house demolition.

(ii) Land compensation, restoration of food production, and employment had mixed results. Despite the smooth implementation of land compensation, the restoration of production and livelihoods had many challenges. The land-based options remained feasible because there were remaining land and existing expertise; but, it was up to affected households to decide where to invest their compensation funds. Most affected households were expected to invest land compensation money into crop restructuring or fruit tree plantation, for example. However, most people wanted to work in cities and towns that provide employment options. The postresettlement income of surveyed affected households mostly came from nonagricultural sources. Restoring the capacity of the village agricultural production and sustaining increased income remain important.

(iii) Restorations of community assets, cultural resources, and living environment are mostly complete. New village roads provide better access to towns and markets. Restoration of cultural squares and tourism training will benefit affected ethnic minority groups. Affected households should fully benefit from these facilities if they are well-maintained and integrated with other activities, such as livelihoods. Good coordination between project agencies and local governments is important.

(iv) Social inclusion and empowerment measures were mostly implemented. These measures focused on skills training and employment targets for women and voluntary enrolment in social endowment insurance schemes. Consultations, skills trainings, and employment included ethnic minorities and women.

(v) Health and education services were not major issues under the project. Schools and health clinics were not inundated. New roads also improved access to schools and health facilities. 


\section{Monitoring and Evaluation of Resettlement}

Regular monitoring and evaluation ensure that the resettlement plan is implemented well, and its intended outcomes are achieved. Resettlement monitoring and evaluation are as important as resettlement impact assessments and planning. The Yudongxia project had provisions for internal and external monitoring. As part of domestic requirements, a resettlement supervision agency provided regular supervision of the LAR activities onsite during project implementation. The Guizhou Provincial Resettlement Bureau inspected resettlement implementation in August 2014. In addition to meeting the ADB requirements, an independent agency was engaged for external resettlement monitoring and evaluation. The agency has since produced five monitoring reports, which focused on the delivery of compensation and relocation; and a postresettlement draft evaluation report. 


\section{Involuntary Resettlement and Sustainable Development \\ Conceptual Framework, Reservoir Resettlement Policies, and Experience of the Yudongxia Reservoir}

Development projects displace about 10 million people globally each year, and reservoir projects cause the most severe impacts. Involuntary resettlement is a complex issue, and requires sufficient knowledge, policies, and practices to manage it successfully, particularly in reservoir projects. This paper synthesizes the conceptual framework on involuntary resettlement, the policies of the People's Republic of China on reservoir-related resettlement, and the experience of the Yudongxia Reservoir. Find out how resettlement issues can be managed successfully through policies and practices in reservoir projects, focusing on sustainable development outcomes for relocated people.

\section{About the Asian Development Bank}

ADB's vision is an Asia and Pacific region free of poverty. Its mission is to help its developing member countries reduce poverty and improve the quality of life of their people. Despite the region's many successes, it remains home to a large share of the world's poor. ADB is committed to reducing poverty through inclusive economic growth, environmentally sustainable growth, and regional integration.

Based in Manila, ADB is owned by 67 members, including 48 from the region. Its main instruments for helping its developing member countries are policy dialogue, loans, equity investments, guarantees, grants, and technical assistance. 